\title{
A Hybrid MCDM for Private Primary School Assessment Using DEMATEL Based on ANP and Fuzzy Cognitive Map
}

\author{
Adil Baykasoglu* \\ Department of Industrial Engineering, Dokuz Eylül University \\ Tinaztepe, Izmir 35160, Turkey \\ Zeynep D. U. Durmusoglu \\ Department of Industrial Engineering, University of Gaziantep \\ Gaziantep 27310, Turkey \\ E-mail:unutmaz@gantep.edu.tr
}

Received 10 August 2012

Accepted 1 April 2014

\begin{abstract}
Primary school selection is actually a decision making problem that should be supported with several source of information. Parents usually handle this problem in an unstructured manner which is indeed a fuzzy mental ranking of schools with respect to the effectiveness. In this study, an analytical hybrid multiple criteria decision making $(\mathrm{MCDM})$ model is proposed and explained with details for private primary school selection problem. A case study indicating primary school choices of parents in Turkey is also presented.
\end{abstract}

Keywords: Private primary school selection, ANP, DEMATEL, FCM

\section{Introduction}

Education is very vital to individuals both for their personal and professional accomplishments. It is well known that differences in pupil achievement are not only related to differences in intelligence and socioeconomic background but also to differences between schools. ${ }^{1}$ Therefore, level and quality of school can be an essential indicator of distinguishing one individual from the others. Level of education and obtained skills have been perceived as the individual's capability to learn and make use of the knowledge to achieve a variety of tasks and goals. In addition to that, various studies in the scientific literature have shown that parent decisions about choice of schools among several school alternatives could certainly be beneficial to academic performance of students. ${ }^{2,3,4,5,6,7}$ In this perspective, parents have been looking for the best possible school for their children especially for the primary/ elementary schools since the fundamental education is carried out at these schools. More and more people are, therefore, demanding a proper education, which can have the negative effects, if not dealt with effectively. ${ }^{8}$ The main objective of primary school selection is finding for a school that will make the education as rewarding as possible. Although it is expected that the schools to be homogenous environments for learning and instruction, they differ from one another physically, socially and pedagogically., ${ }^{9,10}$ With the settlement of privately owned primary schools, number of options and the variety of services proposed by each of these schools has also increased. As indicated by Woods ${ }^{11}$, schools

*Corresponding author: adil.baykasoglu@deu.edu.tr, Tel: +902323017600 
are operating in a progressively competitive environment. As a result there has been increasing interest among both educationists and marketers in the relationship between schools and parents, in particular in the processes and reasons behind parents' choice of school for their children. ${ }^{12}$ Privately-owned schools have developed their different marketing strategies to attract more students considering the preferences of parents. Therefore, parents have been faced with an increasing number of options in choosing school accompanying different extensions of the options which vary from school to school.

Although parents have been exercising on these multiple choices in several ways, a rationale has not been established yet to solve this multi-criteria and multi-optional problem of "private primary school selection". The most common and casual way has been selection of schools based on the locations at the living places or at neighborhood settings. However, to do school selection optimally, parents need to have a clear understanding of the rules of the school assignment process, know about all candidate schools, and engage in strategic school selection and ordering based on their expectations about other parents' choices. ${ }^{13}$ In this demanding process, parents have ample opportunity to make technical errors about the rules as well as make errors of judgment in selecting and ordering the schools choices. ${ }^{13}$ However, an analytical approach, which includes the individual preferences along with the expert knowledge, for private primary school selection would be invaluable both for parents and students.

Although there have some empirical studies on school selection problem; such as Desena ${ }^{14}$, Kindle and Colby $^{15}$, Knights and Kennedy ${ }^{16}$, Saporito and Lareau ${ }^{17}$, there is still a lack of research and implementation regarding the private primary school selection of parents and students. It is already known that, rational choice theory informs most school choice plans. This theory suggests that parents are utility maximizers who make decisions from clear value preferences based on calculations of the costs, benefits, and probabilities of success of various options; that they are able to demand action effectively from local schools and teachers; and that they can be relied upon to pursue the best interests of their children. 18 Recent researches, however, indicates that the context of parental decision-making is far more complex than the result of individual rational calculations of the economic return of their investment in particular education options. ${ }^{19}$

The reasons that are pushing us to prepare such a study can be summarized as follows:

1. Choosing a primary school is one of the most important decisions that the parents make for their children since the education that the children will have during these formative years will create basis on their skills, attitude and abilities later in life.

2. All primary private schools charge different amount of fees, and parents are not sure what they pay for exactly.

3. Since specific skills and tendencies of children can be very different (their weaknesses and talents), it may be very difficult to match the suitability of schools with the specific requirements.

4. Selecting a primary school is a decision taken with anxiety for many parents. To make the decision easier, and to give parents confidence in that decision, it is essential they employ a scientific and structured methodology like the most favorable MCDM approach presented in this study.

Therefore; the main expected benefit of this study is to develop a general and robust approach for private primary school selection and to address the challenge of private primary school selection problem through the proposed hybrid MCDM model.

The rest of this paper is organized as follows. In section 2 and 3, methodology for ANP and FCM are reviewed respectively. Subsequently, steps of the proposed hybrid MCDM model for selecting the private primary school is presented in section 4. Application of the proposed scheme is illustrated in the section 5. Finally conclusions are presented in the section 6 .

\section{Research Framework and the Methodology}

Multi-criteria decision-making method is widely used for evaluation, in which, there are a number of predetermined alternatives, associated with a level of the achievement of the criteria, based on these criteria, the final decision ${ }^{20,21}$. Therefore, this work is aimed to propose an integrated multiple criteria decision making (MCDM) model to solve the private primary school selection problem. As Ruan et al. ${ }^{22}$ declared, real world decisions often made in the presence of multiple, conflicting, and incommensurate criteria. Real world decisions often made in the presence of multiple, conflicting, and incommensurate criteria. In this perspective, a hybrid MCDM model, integrating analytic network process (ANP) and fuzzy cognitive maps (FCMs) is proposed to solve the private primary school selection problem through the use of expert 
knowledge. For this study, we have created a discussion panel with 45 education experts to form a basis about the decision making in primary school selection. Half of the members of this discussion panel have been selected from the members of education faculty of University of Gaziantep and Dokuz Eylül University. The remaining half has been selected from different private school managers both in Gaziantep and İzmir. Panel members arranged several online meetings until they have consensus on the issue. Experts decided about the factors that FCM includes deriving the influence among criteria which will be inserted into the ANP model. Since the fundamental objective of this study is to provide a robust decision making model for parents in parallel to their preferences. For testing purposes, 300 parents who have at least one child attending to primary school have been randomly surveyed both in Gaziantep and İzmir.

We preferred a hybrid model since hybrid models are capable of combining strengths of two or more models and they are known to yield more promising results when compared to classical MCDM models. For the hybrid MCDM model proposed through this work, ANP has been considered as the essential component of the hybrid model due to its superiority over the some other known MCDM models assuming the independence of preferences. The real-life situation usually emerges the dependence and the feedback effects simultaneously while making decisions ${ }^{23}$ as it is in private primary school selection problem. The ANP was proposed by Saaty and Vargas $^{24}$ to overcome the problem of dependence and feedback among criteria or alternatives. ${ }^{23}$ ANP has been a robust and reliable MCDM model. Although the ANP have been widely used in various applications, two main problems have been highlighted as follows. ${ }^{23}$ The first is the problem of comparison. However the interrelations of factors in classical ANP are expressed using verbal comparisons. In addition to that, these comparisons are not analytically verified. Questions like "How much importance does a criteria have compared to another criterion with respect to our interests or preferences?' can be hard even for the expert to answer due to some questions are anti-intuitive. ${ }^{23}$ Furthermore, the key for the ANP is to determine the relationship structure among features in advance. ${ }^{25}$ The different structure results in the different priorities. ${ }^{23}$ However, it is usually hard for the decision maker to give the true relationship structure by considering many criteria. ${ }^{23}$ From the contents of the ANP mentioned above, it is clear that the key for the ANP is to determine the network structure among all features in advance ${ }^{25}$ and answer the questions precisely. ${ }^{23}$ However, sometimes both of them are hard for the decision maker to give. Therefore, hybrid models including ANP have focused to overcome the above mentioned handicaps.

On the other hand, fuzzy cognitive maps (FCMs) could clarify the structure among criteria ${ }^{23,26,27,28,29}$ for solving MCDM problems in preferential weights by using the ANP. ${ }^{29}$ Therefore, we enriched the classical ANP with two forms of FCM whose threshold functions are linear and hyperbolic tangent. Subsequently, steady state matrix obtained from FCM has been used to construct "network relation maps" (NRMs) among criteria for private primary school selection problem. In parallel to the Chen et al. ${ }^{30}$, NRMs have been multiplied with the corresponding values in the unweighted super matrix evaluated by the decision makers/parents. Subsequently, grades for alternative private primary schools have been calculated using the evaluations regarding the facilities provided by these schools.

Finally, the "cost/benefit" ratio is calculated to rank the alternatives in terms of the corresponding cost for a unit of benefit. Although, a private primary school alternative that maximize benefits appears to be more preferable; variety of the cost for the alternatives, requires adjustment among the alternatives. Therefore, the school with minimum "cost/benefit" ratio is expected to be selected.

It is remarkable to state here that during the implementation of these steps, some software can ease the several mathematical operations and enhance the repeatability of these operations for future use. We used a favorable software package SuperDecisions ${ }^{31}$ for visualizing the proposed model and performing the calculations of ANP. Matlab code is also used to run the FCM calculations to be inserted into SuperDecisions as the influence weights.

\section{Analytic Network Process (ANP)}

In this study ANP is implemented as a part of the proposed MCDM model which is integrated with FCMs. Analytic Hierarchy Process (AHP) is known as a particular case where factors and sub-factors are not assumed to be independent of each other. ${ }^{32}$ ANP has the ability of capturing numerous decision making problems by incorporating a feedback mechanism and interactions among the dimensions as well as the hierarchical relationship of alternatives. ${ }^{33,34,35,36,37,38}$ By using ANP, multiple expert and multiple criteria features of decision making problems can be handled together to formulate a network of factors/dimensions and criteria. 
ANP is based on "comparative judgments." Intangible values are quantified using the proposition of ratio scales and the criteria are compared. That is, a comparison between two dimensions is made according to the intensity and dominance. The priorities of criteria determine the weight factors with respect to the goal. The comparisons are extensively made by experts.

The steps of constructing an ANP model starts with structuring the network that consists of hierarchies and dependencies. The goal is considered to be the origin of the network, where the alternatives are assessed by their influences with respect to the defined goal(s). Subnetworks are built according to nature of the problem under each parent criterion. The feedback structure stands for interactions that converge toward the goal.

ANP has been recognized as a robust approach and therefore it has been applied in a wide area of research such as to project selection (Meade and Presley ${ }^{39}$ ), production planning (Karsak et al. ${ }^{40}$, Meade and Sarkis ${ }^{41}$ ), and strategic decision (Leung et al. ${ }^{42}$, Ravi and Shankar ${ }^{43}$ ). There are also several examples of hybrid models in the literature which combine ANP with several MCDM techniques to build reliable influence relationship among the dimensions and criteria. Some of these studies are as follows. Tsai and $\mathrm{Chou}^{44}$ proposed a novel hybrid model for selecting optimal management systems under resource constraints, and illustrated the practical application of such a model through an example. Their model first applied the Decision Making Trail and Evolution Laboratory (DEMATEL) approach to construct interrelations among criteria that organizations require. Subsequently they applied ANP to obtain the criteria weights. Finally, they have integrated ANP with a zeroone goal programming (ZOGP) model to obtain optimal alternatives with desired organizational benefits by fully utilizing limited resources. In $2008, \mathrm{Wu}^{45}$ proposed a robust MCDM model that is considering the interactions among criteria based on a combined ANP and DEMATEL approach to help companies that need to evaluate and select knowledge management strategies. Chen and Chen ${ }^{46}$ utilized DEMATEL, fuzzy ANP and technique for order preference by similarity to an ideal solution (TOPSIS) to develop an innovation support system (ISS) that considers the interdependence and the relative weights of each measurement criterion. Chen et al. $^{30}$ combined the DEMATEL with the ANP to calculate the relative weights of the criteria under interdependence and feedback. They have investigated the environment watershed problem to demonstrate their proposed novel hybrid MCDM model. Büyüközkan and Öztürkcan ${ }^{47}$ developed a novel approach based on a combined ANP and DEMATEL technique to help companies determine critical Six Sigma projects and identify the priority of these projects especially in logistics companies. They applied DEMATEL approach to construct interrelations among criteria. They used the weights of criteria obtained through ANP to calculate the weighted super matrix. Tsai and $\mathrm{Hsu}^{48}$ presented a novel hybrid model, which could cope with the interdependencies between the criteria, to select the optimal cost of quality (CoQ) model for an organization. As a result, their integrated model has been able to assist quality managers in administrating their requirements and resource constraints on selecting the optimal CoQ model developments. Ho et al. ${ }^{49}$ proposed a novel MCDM model, including DEMATEL, ANP, and VIKOR for exploring portfolio selection based on capital asset pricing model (CAPM). They probed into the influential factors and relative weights of risk-free rate, expected market return, and beta of the security.

In 2011, Yang et al. ${ }^{50}$ proposed an information security risk-control assessment model that could improve information security for these companies and organizations using an MCDM model combining VIKOR, DEMATEL, and ANP to solve the problem of conflicting criteria that show dependence and feedback.

\section{Fuzzy Cognitive Maps (FCMs)}

Decision making has been difficult than ever before with the increasing variety of demands and the number of options interacting with each other. Therefore, many researchers have focused on finding a robust and valid decision making model to overcome existing tackles of this complexity. In addition to the requirement of selecting or developing a robust model, the essential difficulty of constructing a decision making model has been defining the relations of factors and their influences properly. In the literature, there have been several hybrid models combined with MCDM approaches which are capable of incorporating the relations of factors and their influences on each other. In this content, cognitive map (CM) has been a powerful visual tool to reflect the beliefs and knowledge of public 
or experts on a situation or field, identifying the causes, effects and the relations between them.

This qualitative technique has been enhanced by several researchers to make it more quantifiable and appropriate to model the decision making problems. FCMs have emerged as the enhanced version of CM. FCM, which is a fuzzy signed oriented graph with feedback, was introduced by Kosko. ${ }^{51}$ FCMs are models which are used to analyze how a system operates based on defined variables. FCM which incorporates ideas from artificial neural networks and fuzzy logic, models the worlds as a collection of concepts and causal relations (causality) between concepts. Therefore, it is possible to find various studies incorporating with FCMs as an internal part of decision support or system analysis to determine interrelations. ${ }^{52,53,54} \mathrm{Yu}$ and Tzeng $^{23}$ succeeded further and they have developed fuzzy decision maps (FDMs), which incorporates the eigenvalue method, FCM and the weighting equation, for MCDM model. Their model cannot be categorized as a hybrid MCDM model but not also a classical FCM which just give the interrelations among the factors. They have used FCM and assigned corresponding weights to obtain a final decision. For mathematical representation of their FDM, they ${ }^{23}$ have used 4-tuples demonstrated with $(\mathrm{N}, \mathrm{E}, \mathrm{C}, f)$ where $\mathrm{N}=\left\{\mathrm{N}_{1}, \mathrm{~N}_{2}, \ldots, \mathrm{N}_{\mathrm{n}}\right\}$ denotes the set of $\mathrm{n}$ objects, $\mathrm{E}$ denotes the connection matrix which is composed of the weights between objects, $\mathrm{C}$ is the state matrix, where $\mathrm{C}^{(0)}$ is the initial matrix and $\mathrm{C}^{(\mathrm{t})}$ is the state matrix at certain iteration $\mathrm{t}$, and $f$ is a threshold function, which indicates the weighting relationship between $\mathrm{C}^{(\mathrm{t})}$ and $\mathrm{C}^{(\mathrm{t}+1)}$. Since some formulations of FDMs are common to this study, details will be discussed in the methodology section.

It should be stated here that, another favorable and robust model for determining the interrelations among the factors is DEMATEL. It was first introduced by Gabus and Fontela ${ }^{55}$ in 1973. But the recent findings have indicated that DEMATEL is the specific case of FCM where the threshold function is linear. It has been proved that both FCM and DEMATEL have the same direct and indirect influence matrix. ${ }^{56}$ Therefore, FCM with linear threshold function is considered as equivalent of DEMATEL.

\section{Stepwise Description of the Proposed Selection Scheme}

Structural MCDM problems involve determining the best alternatives by considering dependence and feedback effects among criteria. ${ }^{23,56}$ In order to deal with this problem, the crucial point is to derive the global weights by considering the dependence and feedback effects. ${ }^{23}$ As we know, due to the problem of compound and interaction effects, it is hard for decision makers to make a good decision using the simple weighted method. ${ }^{23}$ A way to overcome the mentioned problems above is to obtain the information of influences among criteria and then to derive the final weights by considering the influences among criteria. ${ }^{21}$ However, since these criteria may have loop or feedback relationships, it is hard to derive the influences among criteria. ${ }^{23}$ Therefore, we first employ the FCM to derive the influence among criteria which will be inserted into the ANP model. It is remarkable to state here that, the fundamental objective of this study is to provide a robust decision making model for parents in parallel to their preferences. Therefore, in the proposed hybrid MCDM model ANP provides a ground for taking the preferences of parents. On the other hand, the interrelations among the factors are not determined by preferences and since these relations can only be given by experts. In this perspective, FCMs is used in the model to provide a ground for providing interrelations and influences of factors. The steps of proposed model can be summarized as follows:

Step 1: Identification of the main and subfactors/criteria that should be considered during the private primary school selection. A group of experts are employed through this process and they negotiate until they have a consensus.

Step 2: Determination of inter-relations among the main factors. Experts are asked to indicate the direct influence between each factor/element $i$ and factor/element $j$ of the others, as indicated by $a_{i j}$, using FCM's rating scale which is between 0-1.

Step 3: Evaluation of the sub-factors by the decision makers/parents based on their individual preferences. This step is run by the help of a structured questionnaire where the decision makers were asked to put the weights on the relative importance of the factors. Scale of Saaty's ${ }^{58} 9$ point priority measurement scale ranging from 1 (equal) to 9 (extreme) used during this process as illustrated at Table $1 .^{59}$ 
Table 1. Fundamental scale for ANP. ${ }^{59}$

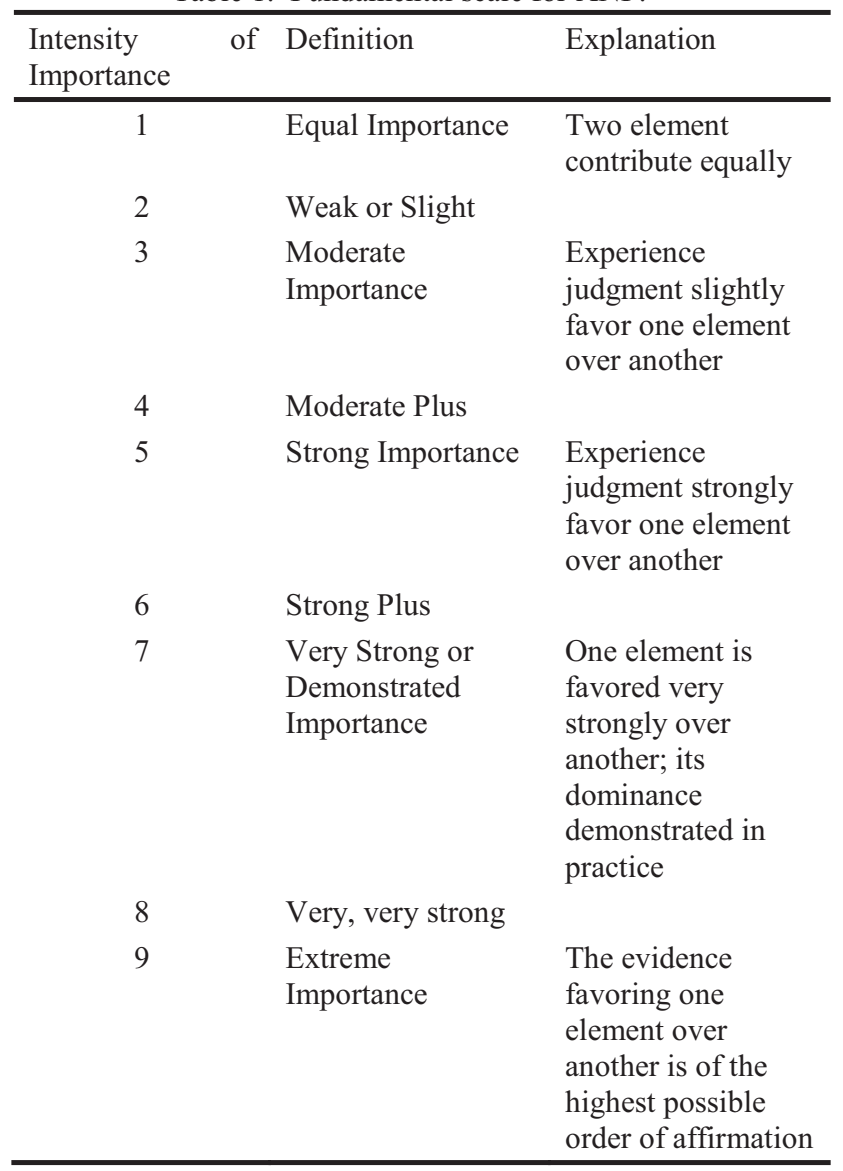

Step 4: Calculation of the influence of the specific criterion to other criteria has been performed using the updating Eq. (1).

$$
C^{(t+1)}=f\left(C^{t} E\right) C^{(0)}=I_{n x n} .
$$

where; $\mathrm{I}_{\mathrm{nxn}}$ denotes the identity matrix.

Since different threshold functions will get the discriminative numerical results ${ }^{57}$ two different $f\left(\mathrm{C}^{\mathrm{t}} \mathrm{E}\right)$ threshold functions have been used within the proposed model. One is the linear function as given in Eq. (2) and other is hyperbolic tangent as depicted in Eq. (3).

$$
\begin{gathered}
f(x)=x \\
f(x)=\tanh (x)=\left(1-e^{-x}\right) /\left(1+e^{-x}\right) .
\end{gathered}
$$

FCM states are iterated successively (by incrementing the value of " $t$ ") until it converges to a steady state or a limit state cycle. The state vector remains unchanged for successive iterations is called a fixed point situation and the sequence of the state vector keeps repeating indefinitely is called a limit state cycle.

Step 5: Weighting the unweighted supermatrix based on steady state matrix. In this step, influences are obtained through Step 4 by using Chen et al.' ${ }^{30}$ approach. The steady state matrix is entered into SuperDecisions to be normalized first and subsequently, to be multiplied with the corresponding values at the unweighted matrix as given in Eq. (4).

$$
\text { Weighted value of }\left(\mathrm{c}_{\mathrm{ij}}\right)=\mathrm{c}_{\mathrm{ij}} * \text { weight }\left(\mathrm{D}_{\mathrm{m}} \mathrm{D}_{\mathrm{n}}\right) \text {. }
$$

where; D denotes dimension (main criteria), $\mathrm{m}$ indicates dimension no of $\mathrm{j}^{\text {th }}$ criteria, $\mathrm{n}$ indicates dimension no of $i^{\text {th }}$ criteria.

Step 6: The stable matrix of ANP when power limit $k$ goes to infinity is calculated.

Step 7: If there are alternatives evaluated before, then alternative's value for the corresponding influence factor is multiplied with the corresponding weight found at the stable ANP matrix to obtain total grade of the each alternative.

Step 8: Cost benefit ratio is calculated. Since the costs of the privately owned primary schools are not included in the model, an approach comparing the costs and the benefits is considered. The annual fee for each school is divided to the total grade obtained at Step 7 as presented in Eq. (5). The school with the minimum cost/benefit value is determined as the best alternative since the cost per one unit of benefit is smaller than the other alternatives.

$$
(\text { Cost / Benefit Ratio })_{\text {school i }}=\text { Annual Fee }{ }_{\text {school } \mathrm{i}} / \text { Total Grade }_{\text {school }} \text {. }
$$

\section{Application of the Proposed Scheme}

In this section, a case study is presented for decisionmakers who involve in the private primary school selection process. The case study was realized in Gaziantep which is one of the biggest cities of Turkey. In this case study, six school alternatives are evaluated. As we cannot provide name of these schools we call them as; School A, School B, School C, School D, School E and School F. A group of education experts (provide school directors, teachers) were asked to identify the factors and the sub-factors that should be considered in school selection. The factors/dimensions and the influence criteria are determined after this structured interviews for private primary school 
selection as presented Table 2. As it can be seen from the table, there are 9 main criteria (education quality, popularity, technology, social activities, foreign language, physical facilities, security, health and transportation services) and 44 sub-criteria. SuperDecisions model was constructed by using the mentioned criteria. The SuperDecisions software implements the ANP for decision making with dependent and feedback developed by Saaty. ${ }^{59}$ The model has a network which is structured of clusters, nodes and links. ${ }^{31}$ Thanks to the software, pairwise comparisons for the nodes in each cluster that belong to a parent node are carried out for all the parent nodes in the model. Superdecisions software provides users to select from several ways to do comparison, such as graphical, verbal, matrix and questionnaire. In addition to this feature, use can shift from questionnaire mode to the matrix mode. In this study first, questionnaire forms were written in the model then they are converted to the matrix mode. The software has an opportunity to calculate the local priorities associated with the judgments. All pairwise matrixes are entered to the unweighted supermatrix automatically. Users can export matrixes to text or excel file. SuperSuperDecisions view of our model is also presented in Fig. 1.

Table 2. The influence dimensions and sub criteria for private primary school selection.

\begin{tabular}{|c|c|c|}
\hline $\begin{array}{l}\text { Dimensions } \\
\text { (Criteria) }\end{array}$ & Sub Criteria (affected) & Affects \\
\hline \multirow[t]{7}{*}{$\begin{array}{l}\text { A-Education } \\
\text { Quality }\end{array}$} & A1-Class Size & $\begin{array}{l}\text { A2,A3,A4,B2,B3,B4,B5,C2,D1 } \\
\text {,E1,E4,F3,F6,F7,F9,H2 }\end{array}$ \\
\hline & A2- Exam Success Rate & $\mathrm{B} 2, \mathrm{~B} 3, \mathrm{~B} 4, \mathrm{~B} 5$ \\
\hline & A3-Teaching Staff & $\begin{array}{l}\text { A2,A4,A5,B2,B3,B4,B5,D3,E1 } \\
\text {,E3,E4,E5,F5 }\end{array}$ \\
\hline & A4-Opportunities for Elective & $\mathrm{A} 2, \mathrm{~A} 3, \mathrm{~B} 2, \mathrm{~B} 3, \mathrm{~B} 4, \mathrm{~B} 5, \mathrm{E} 1, \mathrm{E} 2, \mathrm{E} 3$, \\
\hline & Courses & $\mathrm{E} 4, \mathrm{E} 5$ \\
\hline & A5-Student Tracking & $\mathrm{A} 2, \mathrm{~B} 2, \mathrm{~B} 3, \mathrm{~B} 4, \mathrm{~B} 5$ \\
\hline & A6-Cabinet classrooms & $\begin{array}{l}\mathrm{A} 1, \mathrm{~A} 2, \mathrm{~A} 4, \mathrm{~B} 2, \mathrm{~B} 3, \mathrm{~B} 4, \mathrm{~B} 5, \mathrm{C} 1, \mathrm{C} 2 \\
\mathrm{C} 5, \mathrm{~F} 6\end{array}$ \\
\hline \multirow[t]{5}{*}{ B-Popularity } & B1-Campaigns & $\mathrm{B} 3, \mathrm{~B} 4, \mathrm{~B} 5, \mathrm{~F} 3, \mathrm{I} 3, \mathrm{I} 4$ \\
\hline & B2-Degress Obtained & $\mathrm{B} 3, \mathrm{~B} 4, \mathrm{~B} 5$, \\
\hline & B3-Being Recognized & B4,B5 \\
\hline & B4-Effect of Environment & $\begin{array}{l}\text { B3,B5,C3,C4,D1,D2,D3,D4E1, } \\
\text { E2,E3,F1,F2,F3,F4,F5,F6,F7, } \\
\text { F8,F9,H2,I1,I2 }\end{array}$ \\
\hline & B5-Effect of Advertisement & $\mathrm{B} 3, \mathrm{~B} 4$ \\
\hline \multirow[t]{6}{*}{$\begin{array}{l}\text { C- } \\
\text { Technology }\end{array}$} & $\begin{array}{l}\text { C1-Cine-vision opportunity in } \\
\text { classrooms }\end{array}$ & $\begin{array}{l}\mathrm{A} 2, \mathrm{~A} 4, \mathrm{~B} 3, \mathrm{~B} 4, \mathrm{~B} 5, \mathrm{D} 3, \mathrm{D} 4, \mathrm{E} 4, \mathrm{~F} 5, \\
\mathrm{~F} 6\end{array}$ \\
\hline & $\begin{array}{l}\text { C2-Number of Computers at } \\
\text { School }\end{array}$ & $\mathrm{A} 2, \mathrm{~B} 3, \mathrm{~B} 4, \mathrm{~B} 5, \mathrm{E} 1, \mathrm{E} 4, \mathrm{~F} 6$, \\
\hline & $\begin{array}{l}\text { C3-Internet Access } \\
\text { Opportunity in Classrooms }\end{array}$ & $\mathrm{A} 2, \mathrm{~B} 3, \mathrm{~B} 4, \mathrm{~B} 5, \mathrm{C} 6, \mathrm{D} 3, \mathrm{E} 1, \mathrm{~F} 6, \mathrm{~F} 9$ \\
\hline & $\begin{array}{l}\text { C4-Air-Conditioner } \\
\text { Opportunity in Classrooms }\end{array}$ & $\mathrm{A} 2, \mathrm{~B} 3, \mathrm{~B} 4, \mathrm{~B} 5$ \\
\hline & $\begin{array}{l}\text { C5-Smart Board Opportunity } \\
\text { in Classrooms }\end{array}$ & $\mathrm{A} 2, \mathrm{~B} 3, \mathrm{~B} 4, \mathrm{~B} 5$ \\
\hline & $\begin{array}{l}\text { C6-Tracibility of Courses } \\
\text { Online by the Parents }\end{array}$ & $\mathrm{A} 3, \mathrm{~A} 5, \mathrm{~B} 3, \mathrm{~B} 4, \mathrm{~B} 5, \mathrm{D} 4$ \\
\hline
\end{tabular}

\begin{tabular}{|c|c|c|}
\hline \multirow{5}{*}{$\begin{array}{l}\text { D-Social } \\
\text { Activities }\end{array}$} & D1-Artistic Course & $\mathrm{A} 3, \mathrm{~A} 4, \mathrm{~B} 3, \mathrm{~B} 4, \mathrm{~B} 5$ \\
\hline & Opportunities at School & \\
\hline & $\begin{array}{l}\text { D2- Traveling Opportunities } \\
\text { both Inner City and Outer City }\end{array}$ & $\mathrm{B} 3, \mathrm{~B} 4, \mathrm{~B} 5, \mathrm{D} 1, \mathrm{D} 2$ \\
\hline & D3-Educative Club Activities & $\mathrm{A} 3, \mathrm{~B} 3, \mathrm{~B} 4, \mathrm{~B} 5, \mathrm{E} 4, \mathrm{E} 5, \mathrm{~F} 6$ \\
\hline & D4-Parental School & $\mathrm{A} 5, \mathrm{~B} 3, \mathrm{~B} 4, \mathrm{~B} 5$, \\
\hline \multirow{8}{*}{$\begin{array}{l}\text { E-Foreign } \\
\text { Language }\end{array}$} & E1-Several Foreign Language & $\mathrm{A} 2, \mathrm{~A} 3, \mathrm{~A} 4, \mathrm{~B} 3, \mathrm{~B} 4, \mathrm{~B} 5, \mathrm{D} 3, \mathrm{E} 3, \mathrm{E} 4$ \\
\hline & Learning Opportunities & \\
\hline & $\begin{array}{l}\text { E2-Sister Schoolship in } \\
\text { Foreign Countries }\end{array}$ & $\begin{array}{l}\mathrm{A} 2, \mathrm{~A} 4, \mathrm{~B} 3, \mathrm{~B} 4, \mathrm{~B} 5, \mathrm{D} 2, \mathrm{D} 3, \mathrm{E} 1, \mathrm{E} 3, \\
\mathrm{E} 4\end{array}$ \\
\hline & E3-Foreign Teacher & $\mathrm{A} 2, \mathrm{~A} 3, \mathrm{~A} 4, \mathrm{~B} 2, \mathrm{~B} 3, \mathrm{~B} 4, \mathrm{~B} 5, \mathrm{E} 1, \mathrm{E} 2$, \\
\hline & $\begin{array}{l}\text { Opportunity for Foreign } \\
\text { Language }\end{array}$ & $\mathrm{E} 4, \mathrm{E} 5$, \\
\hline & E4-Foreign Language Class & $\mathrm{A} 2, \mathrm{~A} 3, \mathrm{~A} 6, \mathrm{~B} 3, \mathrm{~B} 4, \mathrm{~B} 5, \mathrm{E} 5, \mathrm{~F} 4, \mathrm{~F} 6$ \\
\hline & E5-Foreign Language & $\mathrm{A} 2, \mathrm{~B} 3, \mathrm{~B} 4, \mathrm{~B} 5$ \\
\hline & Exams/Competitions & \\
\hline \multirow{10}{*}{$\begin{array}{l}\text { F-Physical } \\
\text { Facilities }\end{array}$} & F1-Astra Pitch & $\mathrm{B} 3, \mathrm{~B} 4, \mathrm{~B} 5, \mathrm{~F} 2, \mathrm{H} 1$ \\
\hline & F2-Xystus for Sport Activities & $\mathrm{B} 3, \mathrm{~B} 4, \mathrm{~B} 5, \mathrm{~F} 4$, \\
\hline & F3-Eating Hall & $\mathrm{B} 3, \mathrm{~B} 4, \mathrm{~B} 5, \mathrm{G} 2$ \\
\hline & F4-A Hall for Several Shows & B3,B4,B5,D1,D3,D4 \\
\hline & F5-Science Laboratory & $\mathrm{A} 2, \mathrm{~A} 4, \mathrm{~B} 3, \mathrm{~B} 4, \mathrm{~B} 5$ \\
\hline & F6-Informatic Classroom & $\mathrm{A} 2, \mathrm{~A} 3, \mathrm{~A} 4, \mathrm{~B} 3, \mathrm{~B} 4, \mathrm{~B} 5, \mathrm{C} 2, \mathrm{C} 3, \mathrm{E} 4$ \\
\hline & F7-Swiming Pool & A4,B3,B4,B5,D3,G2,G3,H1 \\
\hline & F8-Botanical Garden & $\mathrm{A} 2, \mathrm{~B} 3, \mathrm{~B} 5$ \\
\hline & F9-Library & $\mathrm{A} 2, \mathrm{~B} 3, \mathrm{~B} 4, \mathrm{~B} 5, \mathrm{G} 2, \mathrm{G} 3$ \\
\hline & G1-Location of School & $\mathrm{A} 3, \mathrm{~B} 3, \mathrm{~B} 4, \mathrm{~B} 5, \mathrm{C} 3, \mathrm{~F} 1, \mathrm{~F} 2, \mathrm{~F} 3, \mathrm{~F} 4$, \\
\hline \multirow[t]{3}{*}{ G-Security } & & F5,F6,F7,F8,F9,G2,G3,H1 \\
\hline & G2-Security Staff & $\mathrm{B} 3, \mathrm{~B} 4, \mathrm{~B} 5$ \\
\hline & $\begin{array}{l}\text { G3-Security Systems (Camera, } \\
\text { Censoring) }\end{array}$ & B3,B4,B5 \\
\hline \multirow[t]{3}{*}{ H-Health } & H1-Medical Room's Staff & $\mathrm{B} 3, \mathrm{~B} 4, \mathrm{~B} 5, \mathrm{H} 2$ \\
\hline & H2-Health Controls & $\mathrm{B} 3, \mathrm{~B} 4, \mathrm{~B} 5, \mathrm{H} 1$ \\
\hline & I1-Recognation of & B3,B4,B5,I3 \\
\hline I- & Transportation Service & \\
\hline \multirow[t]{3}{*}{$\begin{array}{l}\text { Transportati } \\
\text { on Service }\end{array}$} & $\begin{array}{l}\text { I2-Transportation Quality- } \\
\text { Service }\end{array}$ & $\mathrm{B} 3, \mathrm{~B} 4, \mathrm{~B} 5, \mathrm{I} 3, \mathrm{I} 4$ \\
\hline & $\begin{array}{l}\text { I3-Quality of Vehicles used in } \\
\text { Transportation }\end{array}$ & B3,B4,B5,I1,I2,I4 \\
\hline & I4-Transportation Pricing & $\mathrm{B} 3, \mathrm{~B} 4, \mathrm{~B} 5, \mathrm{I} 3$ \\
\hline
\end{tabular}

It should be stated that costs could have been included as one of the factors that has effect on the school selection. However, in many complex decisions, cost factor is preferred to be set aside until the benefits of the alternatives are evaluated since handling costs together with benefits can yield emotional responses. This tackle is handled through the "cost/benefit analysis" which is considered as the final step of the decision model.

Subsequently, as stated at the Step 2, experts were asked to use FCM's rating scale to evaluate the interrelationships among the main factors. The average initial direct-relation $9 * 9$ matrix $\mathrm{A}$ is obtained by pairwise comparisons in terms of the influences and directions between the dimensions is shown in Table 3 .

As the next step, Eq. (1) and Eq. (2) is used to obtain steady state matrix for the FCM with linear threshold function, which is presented in Table 4. Similarly, by using Eq. (1) and Eq. (3), steady state matrix for the FCM with hyperbolic tangent threshold function is obtained as given in Table 5. In addition, we plot the 
cause and effect diagram of main criteria. The causer and effecter (receiver) criteria were determined by using the similar procedure as DEMATEL. First of all $r$ and $c$ as $n \times 1$ vectors, representing the sum of rows and sum of columns of the steady state matrix for the FCM (C) with linear threshold function, were calculated by using the following Equations.

$$
\begin{gathered}
\boldsymbol{r}=\left[r_{i}\right]_{n \times 1}=\left(\sum_{j=1}^{n} C_{i j}\right)_{n \times 1} . \\
\boldsymbol{c}=\left[c_{j}\right]_{1 \times n}^{\prime}=\left(\sum_{i=1}^{n} C_{i j}\right)_{1 \times n}^{\prime} .
\end{gathered}
$$

where superscript ' denotes transpose.

Let $r_{i}$ be the sum of $i^{\text {th }}$ row in steady state matrix for the FCM with linear threshold function. Then $r_{i}$ shows the total effects, both direct and indirect, given by factor i to the other factors. Let $c_{j}$ denotes the sum of $j^{\text {th }}$ column in steady state matrix for the FCM with linear threshold function. Then $\mathrm{c}_{\mathrm{j}}$ shows the total effects, both direct and indirect, received by factor $\mathrm{j}$ from the other factors. $\left(r_{i}+c_{i}\right)$ shows the degree of importance (total sum of effects given and received) that factor $i$ plays in the system. In addition, the difference $\left(r_{i}-c_{i}\right)$ shows the net effect that factor i contributes to the system. When $\left(r_{i}-c_{i}\right)$ is positive, factor $\mathrm{i}$ is a net causer, and when $\left(r_{i}-c_{i}\right)$ is negative, factor $\mathrm{i}$ is a net receiver. ${ }^{29,60}$ Cause and effect diagram for main criteria is given in Fig.2.

After determination of the relationships among the main factors, the ANP method is applied to obtain criteria weights. Initially, the importance of relationships between each criterion is compared by parents. For example, a parent was asked to respond to a series of questions, such as "For the school selection, how much more important is one operation criteria over another?". These pair-wise comparisons are based on the AHP concept, and the plan was graded on a 9-point scale with a score of 1 indicating equal importance and 9 indicating extreme importance of one element over another. As the local weights of these criteria are obtained through the principal eigenvector of comparison, an unweighted supermatrix is generated as presented in Table 6.

Subsequently, by using the unweighted supermatrix and corresponding normalized steady state matrix, weighted supermatrices are obtained. The super-matrix which is weighted with the FCM having the linear threshold 


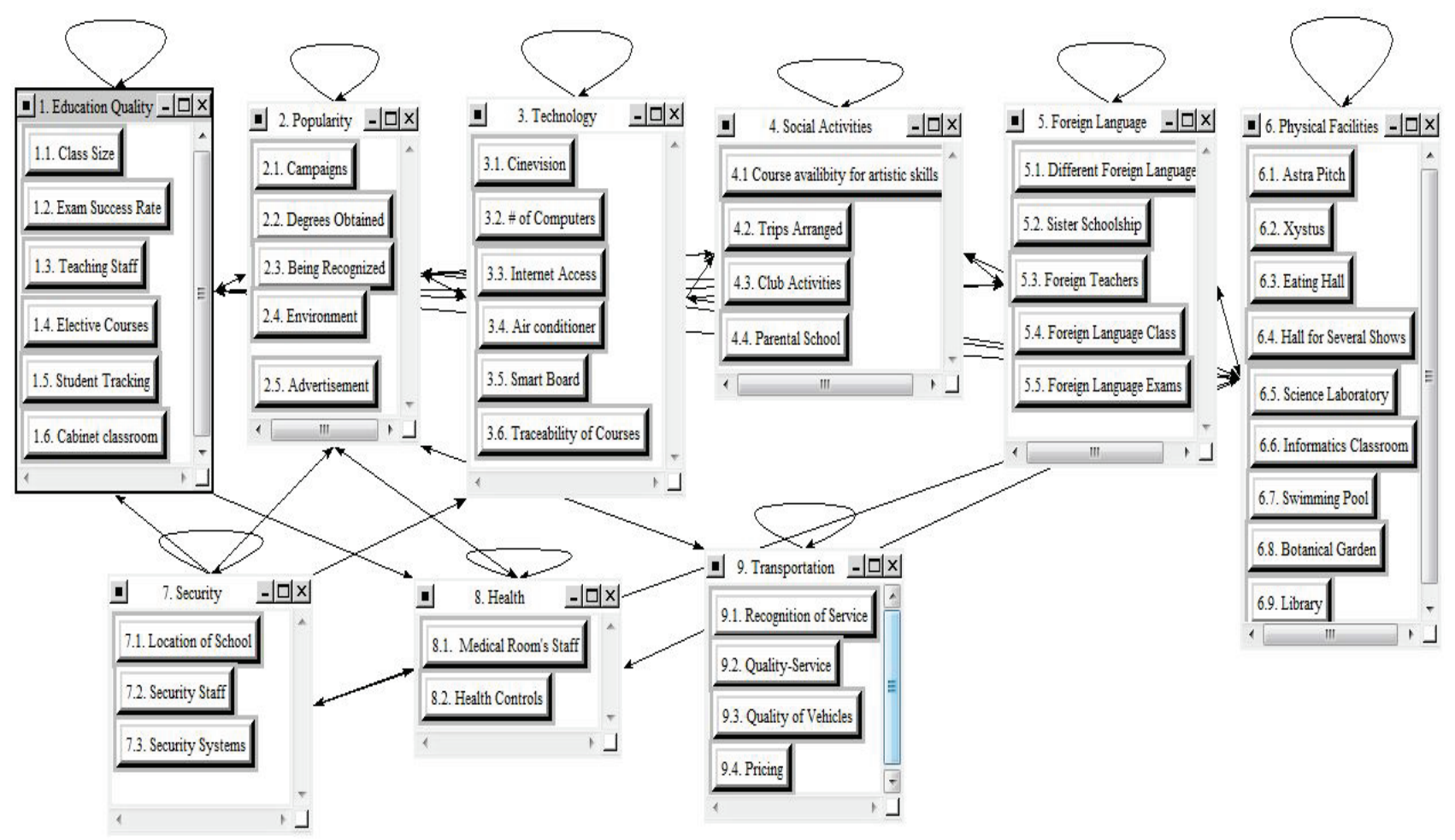

Fig. 1. Model view captured from SuperDecisions

Table 3. Connection matrix composed of weights.

\begin{tabular}{llllllllll}
\hline & $\begin{array}{l}\text { Education } \\
\text { Quality }\end{array}$ & \multicolumn{9}{c}{$\begin{array}{c}\text { Social } \\
\text { Popularity }\end{array}$} & $\begin{array}{l}\text { Technology } \\
\text { Activity }\end{array}$ & $\begin{array}{l}\text { Foreign } \\
\text { Language }\end{array}$ & $\begin{array}{l}\text { Physical } \\
\text { Facilities }\end{array}$ & Security & Health & $\begin{array}{l}\text { Transportation } \\
\text { Service }\end{array}$ \\
\cline { 2 - 11 } Education Quality & 0.1836 & 0.1498 & 0.0097 & 0.0580 & 0.1836 & 0.0097 & 0.0000 & 0.1014 & 0.0000 \\
Popularity & 0.0580 & 0.1546 & 0.0048 & 0.0097 & 0.0338 & 0.0048 & 0.0000 & 0.0097 & 0.0097 \\
Technology & 0.1498 & 0.1208 & 0.1546 & 0.0531 & 0.1401 & 0.1014 & 0.0000 & 0.0000 & 0.0000 \\
Social Activity & 0.1014 & 0.1449 & 0.0000 & 0.1256 & 0.1159 & 0.0242 & 0.0580 & 0.0870 & 0.0970 \\
Foreign Language & 0.1691 & 0.1498 & 0.0000 & 0.1401 & 0.1643 & 0.0048 & 0.0000 & 0.0000 & 0.0000 \\
Physical Facilities & 0.0966 & 0.1449 & 0.1014 & 0.1063 & 0.1014 & 0.1159 & 0.1208 & 0.1159 & 0.0000 \\
Security & 0.1353 & 0.0048 & 0.0048 & 0.0000 & 0.0000 & 0.0048 & 0.1014 & 0.0048 & 0.0000 \\
Health & 0.0000 & 0.0435 & 0.0000 & 0.0000 & 0.0000 & 0.0000 & 0.0000 & 0.1014 & 0.0048 \\
Transportation Service & 0.0000 & 0.0870 & 0.0000 & 0.0000 & 0.0000 & 0.0000 & 0.0000 & 0.0000 & 0.0531 \\
\hline
\end{tabular}

Table 4. Steady state matrix for $f(x)=x$.

\begin{tabular}{|c|c|c|c|c|c|c|c|c|c|}
\hline & $\begin{array}{l}\text { Education } \\
\text { Quality }\end{array}$ & Popularity & Technology & $\begin{array}{l}\text { Social } \\
\text { Activity }\end{array}$ & $\begin{array}{l}\text { Foreign } \\
\text { Language }\end{array}$ & $\begin{array}{l}\text { Physical } \\
\text { Facilities }\end{array}$ & Security & Health & $\begin{array}{l}\text { Transportation } \\
\text { Service }\end{array}$ \\
\hline Education Quality & 0.3465 & 0.3410 & 0.0204 & 0.1513 & 0.3370 & 0.0250 & 0.0131 & 0.1736 & 0.0059 \\
\hline Popularity & 0.1125 & 0.2297 & 0.0096 & 0.0361 & 0.0824 & 0.0105 & 0.0037 & 0.0308 & 0.0131 \\
\hline Technology & 0.3617 & 0.3573 & 0.2074 & 0.1740 & 0.3388 & 0.1512 & 0.0316 & 0.0812 & 0.0058 \\
\hline Social Activity & 0.2420 & 0.3106 & 0.0098 & 0.2070 & 0.2397 & 0.0402 & 0.0833 & 0.1531 & 0.0163 \\
\hline Foreign Language & 0.3349 & 0.3435 & 0.0083 & 0.2407 & 0.3213 & 0.0204 & 0.0183 & 0.0675 & 0.0063 \\
\hline Physical Facilities & 0.3036 & 0.3730 & 0.1460 & 0.2188 & 0.2776 & 0.1617 & 0.1703 & 0.2103 & 0.0071 \\
\hline Security & 0.2069 & 0.0622 & 0.0104 & 0.0251 & 0.0545 & 0.0109 & 0.1160 & 0.0339 & 0.0011 \\
\hline Health & 0.0055 & 0.0601 & 0.0005 & 0.0018 & 0.0040 & 0.0005 & 0.0002 & 0.1144 & 0.0063 \\
\hline Transportation Service & 0.0103 & 0.1129 & 0.0009 & 0.0033 & 0.0076 & 0.0010 & 0.0003 & 0.0028 & 0.0573 \\
\hline
\end{tabular}


Table 5. Steady state matrix for $f(x)=\tanh (x)$.

\begin{tabular}{|c|c|c|c|c|c|c|c|c|c|}
\hline & $\begin{array}{l}\text { Education } \\
\text { Quality } \\
\end{array}$ & Popularity & Technology & $\begin{array}{l}\text { Social } \\
\text { Activity }\end{array}$ & $\begin{array}{l}\text { Foreign } \\
\text { Language } \\
\end{array}$ & $\begin{array}{l}\text { Physical } \\
\text { Facilities }\end{array}$ & Security & Health & $\begin{array}{l}\text { Transportation } \\
\text { Service }\end{array}$ \\
\hline Education Quality & 0.1183 & 0.1058 & 0.0065 & 0.0444 & 0.1169 & 0.0072 & 0.0018 & 0.0627 & 0.0009 \\
\hline Popularity & 0.0381 & 0.0902 & 0.0032 & 0.0089 & 0.0249 & 0.0033 & 0.0005 & 0.0082 & 0.0055 \\
\hline Technology & 0.1079 & 0.0965 & 0.0877 & 0.0456 & 0.1014 & 0.0601 & 0.0052 & 0.0120 & 0.0007 \\
\hline Social Activity & 0.0738 & 0.0994 & 0.0015 & 0.0764 & 0.0780 & 0.0148 & 0.0338 & 0.0547 & 0.0060 \\
\hline Foreign Language & 0.1114 & 0.1061 & 0.0011 & 0.0869 & 0.1080 & 0.0049 & 0.0030 & 0.0108 & 0.0010 \\
\hline Physical Facilities & 0.0813 & 0.1077 & 0.0595 & 0.0709 & 0.0779 & 0.0666 & 0.0699 & 0.0733 & 0.0011 \\
\hline Security & 0.0801 & 0.0109 & 0.0034 & 0.0035 & 0.0089 & 0.0034 & 0.0537 & 0.0074 & 0.0001 \\
\hline Health & 0.0009 & 0.0251 & 0.0001 & 0.0001 & 0.0006 & 0.0001 & 0.0000 & 0.0536 & 0.0027 \\
\hline
\end{tabular}

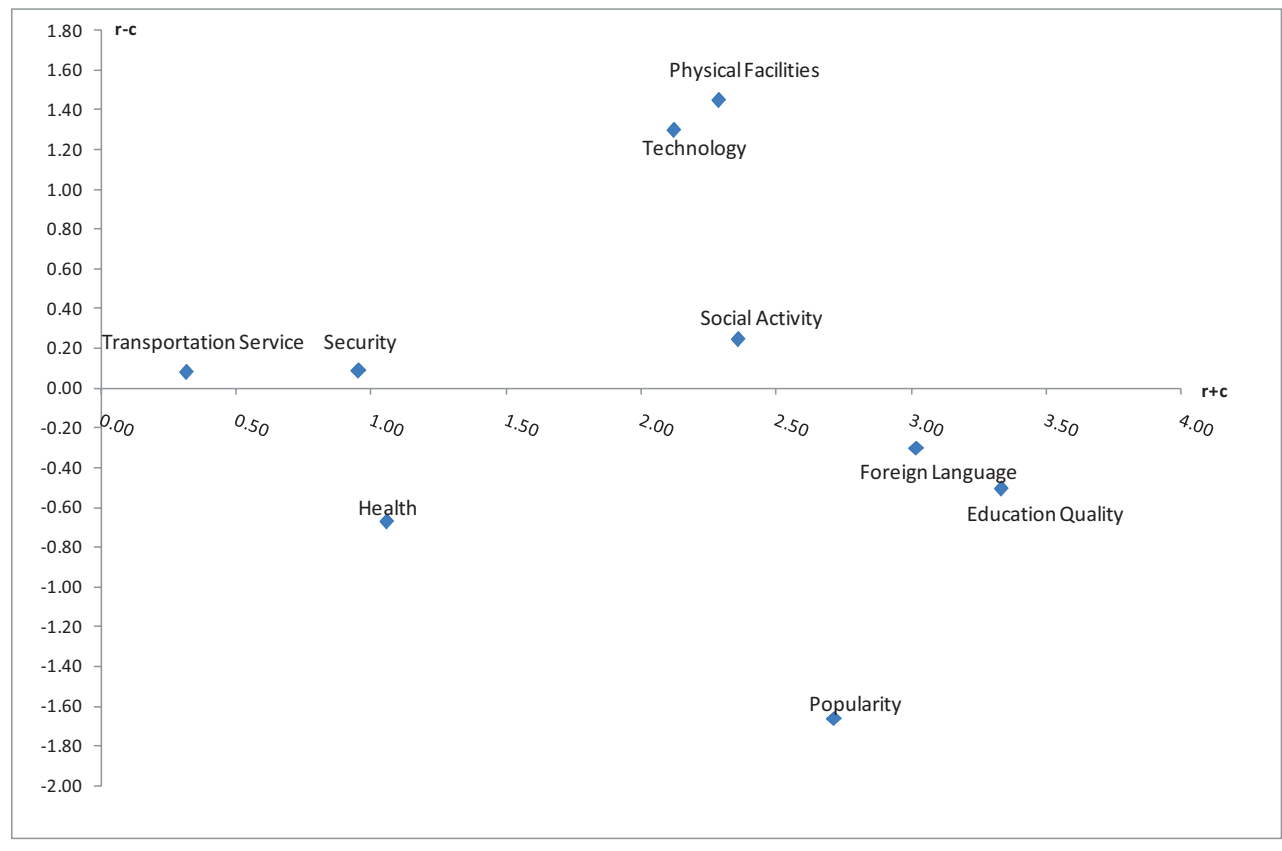

Fig. 2 Cause and effect diagram of main criteria 
ঊ

m

^

=

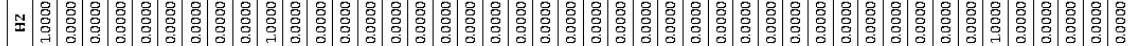

I

m

ฯ

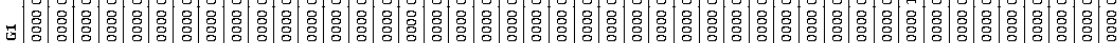

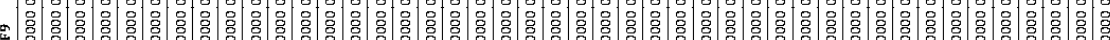

-

«

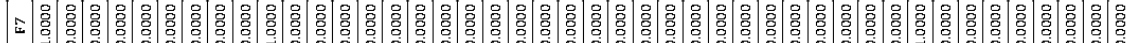

4 客

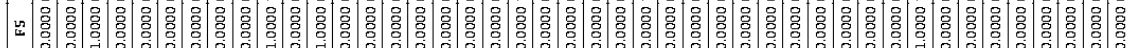

士

m

«

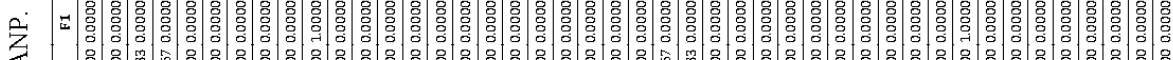

出

宏

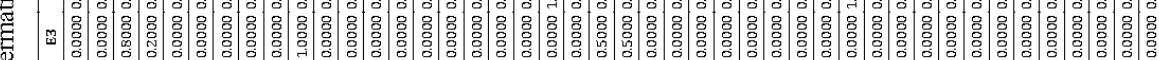

胥

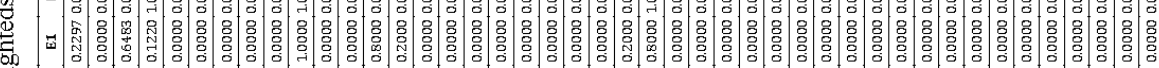

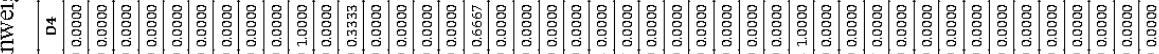

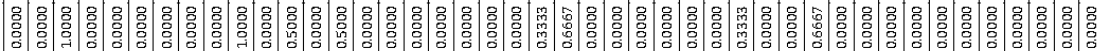

竞

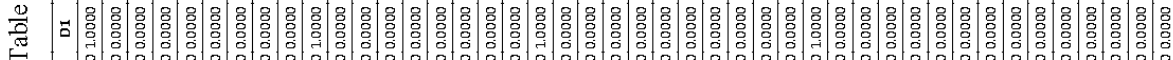

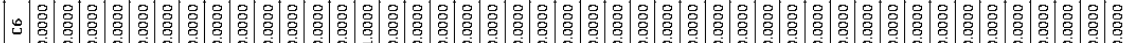

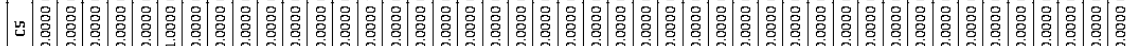

ษ

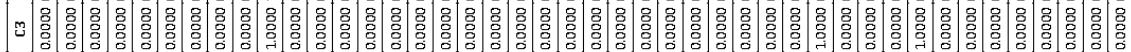

凹

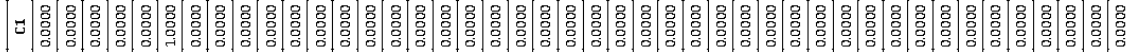

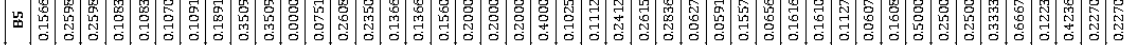

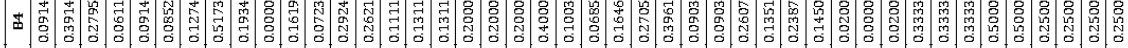

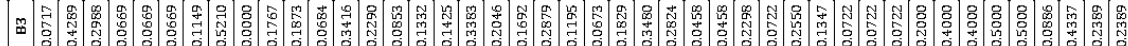

«

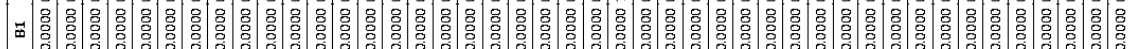

40

ч

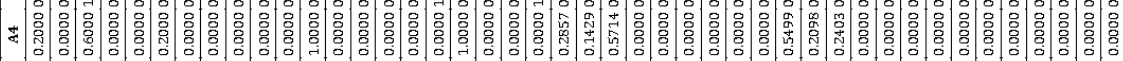

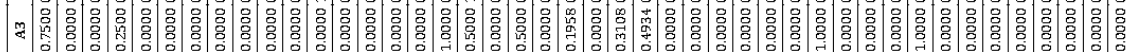

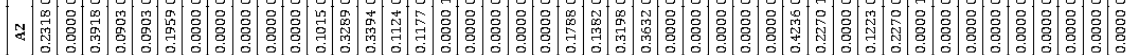

z

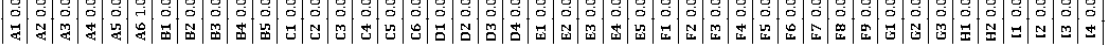

Co-published by Atlantis Press and Taylor \& Francis

Copyright: the authors

625 
Function is presented in Table 7 and the one weighted with hyperbolic tangent is presented in Table 8 .

Based on Table 7 and Table 8 , the limiting power of the weighted supermatrix, where $k$ goes to infinity is calculated and presented at Table 9 for $f(x)=x$ and Table 10 for $f(x)=\tanh (x)$. Each row represents the weight of each criterion.

As seen at the Table 9 and Table 10, the highest priority for the school selection has been "teaching staff" approximately with $12.0 \%$ ratio; oppositely botanic garden, security staff and security systems the factors which has not been considered by the parents.

In this study, six school alternatives are evaluated: School A, School B, School C, School D, School E and School F. As defined at STEP 7, pre-evaluated value of influence factors of an alternative is multiplied with the corresponding weight found at the stable ANP matrix, to obtain the total grade for that alternative. Grades of each alternative are as calculated at Table 11 and Table 12.

As the final step, costs are considered for decision of selecting the private primary school through the cost/benefit analysis. Corresponding annual fees of the alternatives and their normalized values along with the calculated cost/benefit ratios are presented in Table 13 .

School E is appeared to be favorable with the cost/benefit ratio of 0.140 . Although school D appeared favorable in terms of the total grade, the high annual fee has made it less preferable

\section{Concluding Remarks}

Primary school education has been vital to parents both for their personal and professional accomplishments for future. In this perspective, parents have been looking for the best possible primary school for their children. However, they were all faced with several options providing different facilities with different fees. In this context, the treatment of private primary school selection is required to handle several complex factors in a reasonable and rational manner. Arguments in favor of greater school choice rest two propositions: a) that competition among schools for students will help to reduce inefficiencies in the delivery of education, and in doing so, improve educational outcomes, and b) that choice would serve to give more control over educational decisions to parents who in turn would choose good schools for their children. ${ }^{61}$ Thus, in this paper the private primary school selection problem is handled as a kind of multiple criteria decision making (MCDM) problem. The relative weights of the criteria are determined by FCM in conjunction with an ANP. By using the cost/benefit analysis the best alternative is determined. Results showed that if the cost is employed as criteria, choice can be improper.

The feedbacks gathered both from the parents and the experts have indicated that the proposed model is suitable to deal with the school selection problem which is complicated with interdependent criteria.

In addition those findings listed above following specific conclusions address how these results benefit to the parents:

1. Meanwhile selecting a primary school is a decision taken with concern for many parents such scientific and structured methodologies may make the decision easier and give confidence to the parents.

2. Since all primary private schools charge different amount of fees, and parents are not sure what they pay for exactly, the balance between the fees and costs should be carefully assessed. In this respect; as performed in this study; excluding the fee as the main decision factor and then including it while comparing with the weighted benefits of schools can be much practical and beneficial.

3. It is remarkable to state here that; in this study we don't focus on favorable factors on school selection since specific skills and tendencies of children are different (their weaknesses and talents), one school that is suitable for one child may not be suitable for another child. In this regard; with the proposed framework school selection decision that is specific to the child and its family can be supported with experimental judgments.

\section{Acknowledgements}

The first author is grateful to Turkish Academy of Sciences (TUBA) for supporting his scientific studies.

\section{References}

1. H. Brandsma and S. Doolaard, Differences in effectiveness between primary schools and their impact on secondary school recommendations, Sch. Eff. Sch. Improv. 10(4) (1999) 130-450.

2. J. G. Altonji, T. E. Elder and C. R. Taber, Selection on observed and unobserved variables: Assessing the effectiveness of Catholic schools, J. Polit. Econ. 113(1) (2005) 151-184. 
3. J. Angrist, E. Bettinger, E. Bloom, E. King and M. Kremer, Vouchers for private schooling in Colombia: Evidence from a randomized natural experiment, $A m$. Econ. Rev. 92(5) (2002) 1535-1558.

4. J. R. Behrman and E. M. King, Household schooling behaviors and decentralization, Econ. Educ. Rev. 20(1) (2001) 321-341.

5. T. O'Shaughnessy, Parental choice and school quality when peer and scale effects matter, Econ. Educ. Rev. 26(1) (2007) 501-515.

6. M. C. Opdenakker and J. V. Damme, Effects of schools, teaching staff and classes on achievement and well-being in secondary education: similarities and differences between school outcomes, Sch. Eff. Sch. Improv. 11(2) (2000) 165-196.

7. P. Teske and M. Schneider, What research can tell policymakers about school choice?, J. Policy Anal. Manag. 20(4) (2001) 609-631.

8. J. P. Du Plessis, J. A. Van Biljon, C. J. Tolmie and T. Wollinger, A model for intelligent computer-aided education systems, Comp. Educ. 24 (2) (1995) 89-106.

9. H. Bussell, Parental choice of primary school: An application of Q-methodology, Serv. Ind. J. 18(3) (1998) 135-147.

10. E. Kalaoja and J. Pietarinen, Small rural primary schools in Finland: A pedagogically valuable part of the school network, Int. J. Educ. Res. 48 (2009) 109-116.

11. P. A. Woods, Responding to the consumer: Parental choice and school effectiveness, Sch. Eff. Sch. Improv. 14(3) (1993) 205-209.

12. C. Bagley, P. A. Woods and R. Clatter, Scanning the market: School strategies for discovering parental perspectives, Educ. Manag. Admin. 24(2) (1996) 125138.

13. F. Lai, E. Sadoulet and A. Janvry, The adverse effects of parents' school selection errors on academic achievement: Evidence from the Beijing open enrollment program, Econ. Educ. Rev. 28 (2009) 485-496.

14. J. N. DeSena, What's a mother to do? Gentrification, school selection, and the consequences for community cohesion, Am. Behav. Sci. 50 (2006) 241-257.

15. P. Kindle and I. Colby, School selection preferences of public and private university MSW students: A retrospective study, J. Soc. Work Educ. 44 (2008) 97-113.

16. J. A. Knights and B. J. Kennedy, Medical school selection: screening for dysfunctional tendencies, Med. Educ. 40 (2006) 1058-1064.

17. S. Saporito and A. Lareau, School selection as a process: The multiple dimensions of race in framing educational choice, Soc. Probl. 46 (1999) 418-439.

18. L. Bosetti, Determinants of school choice: Understanding how parents choose elementary schools in Alberta, $J$. Educ. Policy 19(4) (2004) 387-405.

19. R. Hatcher, Class differentiation in education: rational choices?, Brit. J. Educ. 19(1) (1998) 5-24.

20. G. Zhang, J. Ma and J Lu, Emergency management evaluation by a fuzzy multi-criteria group decision support system, Stochastic Environmental Research and Risk Assessment. 23(4) (2009) 517-527.

21. J. Lu, J. Ma, G. Zhang, X. Zeng and L. Koehl, Themebased comprehensive evaluation in new product development using fuzzy hierarchical criteria group decision-making method, IEEE Transactions on Industrial Electronics, 58(6) (2011) 2236-2246.

22. D. Ruan, J. Lu, E. Laes, G. Zhang, J. Ma and G. Meskens, Multi-criteria Group Decision Support with Linguistic Variables in Long-term Scenarios for Belgian Energy Policy, J. UCS, 16(1) (2010) 103-120.

23. R. Yu, and G. H Tzeng, A soft computing method for multi-criteria decision making with dependence and feedback, Appl. Math. and Comput. 180(1) (2006) 63-75.

24. T. L. Saaty and L. G. Vargas, Diagnosis with dependent symptoms: Bayes theorem and the analytic hierarchy process, Oper. Res. 46(4) (1998) 491-502.

25. J. W. Lee and S. H. Kim, Using analytic network process and goal programming for interdependent information system project selection, Comput. Oper. Res. 27(4) (2000) 367-382.

26. Y. J. Chih, H. C. Chen, J. Z. Syzu and G. H. Tzeng, Marketing strategy based on customer behavior for the LCD-TV, Int. J. Manag. Decis. Making. 7(2/3) (2006) 143-165.

27. C. Y. Huang and G. H. Tzeng, Reconfiguring the innovation policy portfolios for Taiwan's SIP mall industry, Technovation 27(12) (2007)744-765.

28. J. J. H. Liou, G. H. Tzeng and H. C. Chang, Airline safety measurement using a novel hybrid model, J. Air Transp. Manag. 13(4) (2007) 243-249.

29. G. H. Tzeng, C. H Chiang and C. W. Li, Evaluating intertwined effects in e-learning programs: A novel hybrid MCDM model based on factor analysis and DEMATEL, Expert Syst. Appl. 32(4) (2007)1028-1044.

30. Y. Chen, H. Lien and G. H. Tzeng, Measures and evaluation for environment watershed plans using a novel hybrid MCDM model, Expert Syst. Appl. 37 (2010) 926938.

31. http://www.superdecisions.com (last acess 24.06. 2013)

32. T. L. Saaty, Fundamentals of the analytic network process- Dependence and feedback in decision-making with a single network, J. Syst. Sci. Syst. Eng. 13(2) (2004) 129-157.

33. Y. C. Erensal, T. Gürbüz and Y. E. Albayrak, A multicriteria decision model for architecturing competence in human performance technology, Int. J. Comput. Int. Sys. 3(6) (2010) 815-831.

34. G. Büyüközkan, O. Feyzioglu and G. Çifçi, Fuzzy multicriteria evaluation of knowledge management tools, Int. J. Comput. Int. Sys. 4(2) (2011) 184-195.

35. C. Kahraman, I. Kaya and S. Çebi, Renewable energy system selection based on computing with words, Int. J. Comput. Int. Sys. 3(4) (2010) 461-473.

36. A. Özgen, G. Tuzkaya, U. R. Tuzkaya and D. Özgen, A multi-criteria decision making approach for machine tool 
selection problem in a fuzzy environment, Int. J. Comput. Int. Sys. 4(4) (2011) 431-445.

37. M. Ekmekçioglu, A. C. Kutlu and C. Kahraman, A fuzzy multi-criteria SWOT analysis: An application to nuclear power plant site selection, Int. J. Comput. Int. Sys. 4(4) (2011) 583-595.

38. G. Çifçi and G. Büyüközkan, A fuzzy MCDM approach to evaluate green suppliers, Int. J. Comput. Int. Sys. 4(5) (2011) 894-909.

39. L. M. Meade and A. Presley, R\&D project selection using the analytic network process, IEEE T. Eng. Manage. 49(1) (2002) 59-66.

40. E. Karsak, S. Sozer and S. E. Alptekin, Product planning in quality function deployment using a combined analytic network process and goal programming approach, Comput. Ind. Eng. 44(1) (2002) 171-190.

41. L. M. Meade and J. Sarkis, Analyzing organizational project alternatives for agile manufacturing processes: An analytical network approach, Int. J. Prod. Res. 37(2) (1999) 241-261.

42. L. C. Leung, K. C. Lam and D. Cao, Implementing the balanced scorecard using the analytic hierarchy process $\&$ the analytic network process, J. Oper. Res. Soc. 57(6) (2006) 682-691.

43. V. Ravi and R. Shankar, Analysis of interactions among the barriers of reverse logistics. Technol. Forecast. Soc. 72(2005) 1011-1029.

44. W. Tsai and W. Chou, Selecting management systems for sustainable development in SMEs: A novel hybrid model based on DEMATEL, ANP, and ZOGP, Expert Syst. Appl. 36 (2009) 1444-1458.

45. W. Wu, Choosing knowledge management strategies by using a combined ANP and DEMATEL approach, Expert Syst. Appl. 35 (2008) 828-835.

46. J. Chen and I. Chen, Using a novel conjunctive MCDM approach based on DEMATEL, fuzzy ANP, and TOPSIS as an innovation support system for Taiwanese higher education, Expert Syst. Appl. 37 (2010) 1981-1990.

47. G. Büyüközkan and D. Öztürkcan, An integrated analytic approach for Six Sigma project selection, Expert Syst. Appl. 37 (2010) 5835-5847.

48. W. Tsai and W. Hsu, A novel hybrid model based on DEMATEL- and ANP- for selecting cost of quality model development, Total. Qual. Manag. Bus. 21 (2010) 439-456.

49. J. W. Ho, C. Tsai, G. Tzeng and S. Fang, Combined DEMATEL technique with a novel MCDM model for exploring portfolio selection based on CAPM, Expert Syst. Appl. 38(1) (2011) 16-25.

50. Y. O. Yang, H. Shieh and G. Tzeng, A VIKOR technique based on DEMATEL and ANP for information security risk control assessment, Inform. Science 232 (2013) 482500 .

51. B. Kosko, Fuzzy cognitive maps, Int. J. Man Mach. Stud. 24 (1986) 65-75.

52. O. Coban and G. Secme, Prediction of socio-economical consequences of privatization at the firm level with fuzzy cognitive mapping, Inform. Science 169(1-26) (2005) 131-154.

53. C. D Stylios and P. P. Groumpos, Mathematical formulation of fuzzy cognitive maps, in Proc. 7th Mediterr. Conf. Cont. Automatation, (Haifa, Israel, 1999), pp. 28-30.

54. D. Yaman and S. Polat, A fuzzy cognitive map approach for effect-based operations: an illustrative case, Inform. Sciences 179(41) 2009, 382-403.

55. A. Gabus and E. Fontela, Perceptions of the world problematic: Communication procedure, communicating with those bearing collective responsibility, DEMATEL Report No: 1. (Geneva, Switzerland, Battelle Geneva Research Centre, 1973).

56. G. H. Tzeng, W. H. Chen, R. Yu and M. L. Shih, Fuzzy decision maps: A generalization of the DEMATEL methods, Soft Comput. 14 (2010) 1141-1150.

57. R. Karni, P. Sanchez and V. M. R. Tummala, A comparative study of multiattribute decision making methodologies, Theor. Decis. 29(3) (1990) 203-222.

58. T. L. Saaty, The Analytic Hierarchy Process (McGrawHill, New York, 1980).

59. T. L. Saaty, Decision Making with Dependence and Feedback: The Analytic Network Process (RWS Publications, Pittsburgh, 1996).

60. M. Tamura, H. Nagata and K. Akazawa, Extraction and systems analysis of factors that prevent safety and security by structural models, in 41st SICE Annual Conference, (Osaka, Japan, 2002), pp. 1752-1759

61. D. D. Goldhaber, School choice: An examination of the empirical evidence on achievement, parental decision making, and equity, Educ. Res. 28(9) (1999) 16-25. 


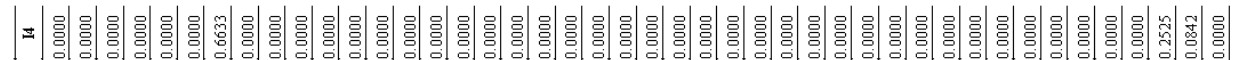

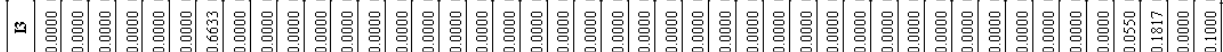

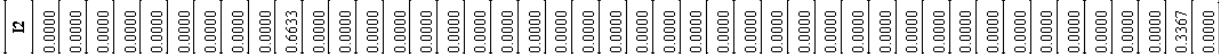

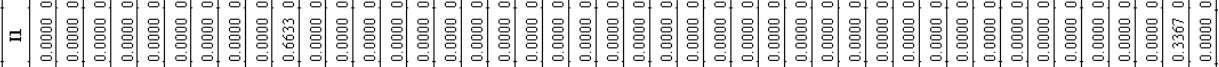

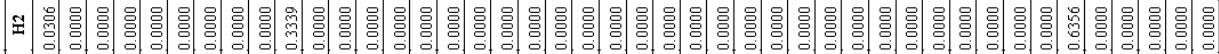

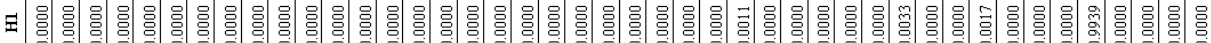

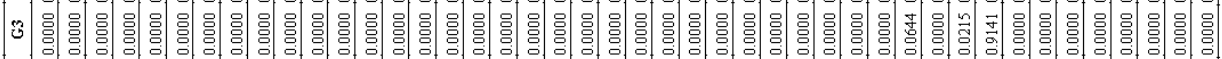

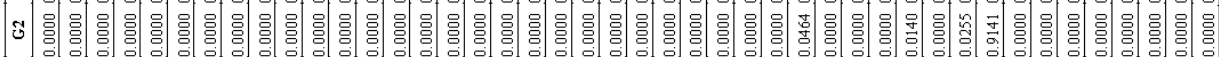

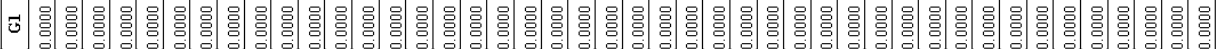

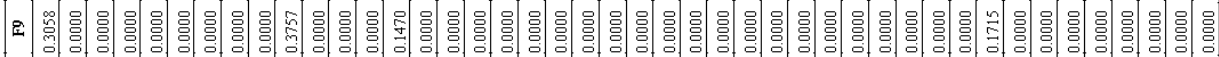

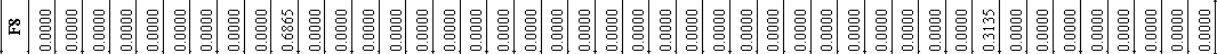

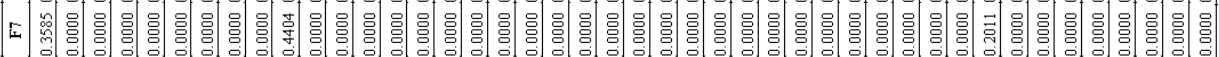

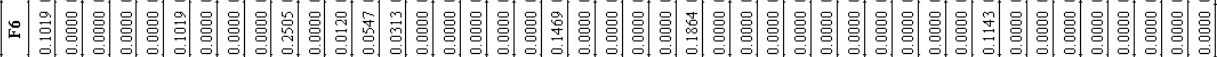

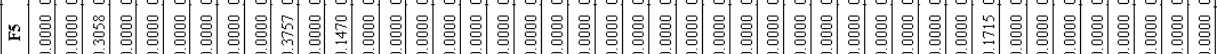

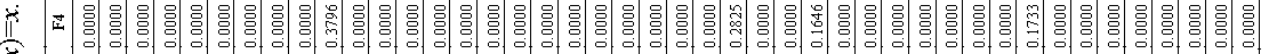

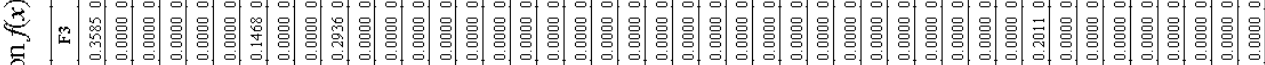

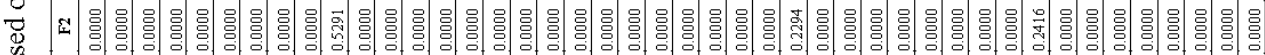

点

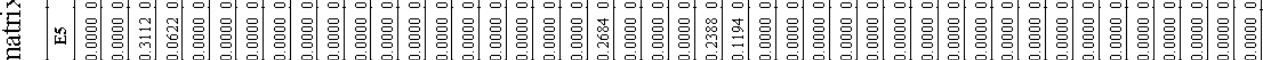

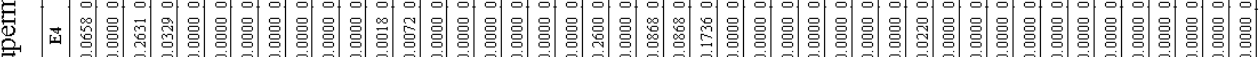

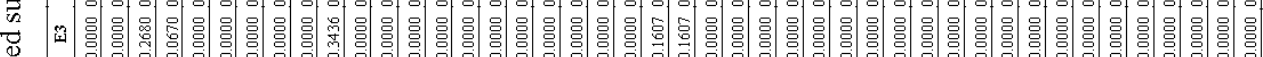

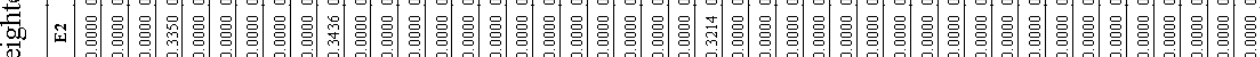

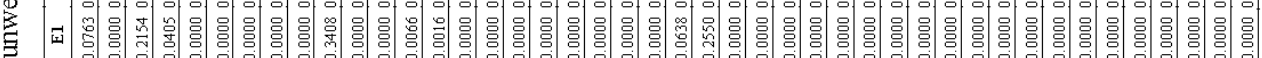

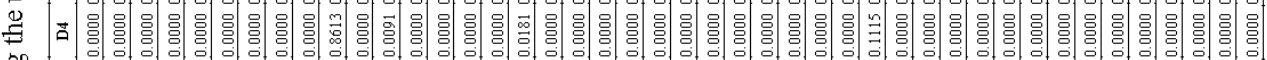

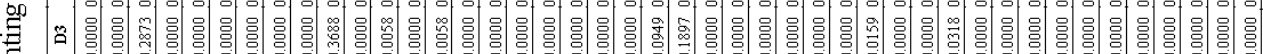
点

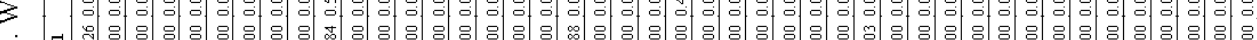

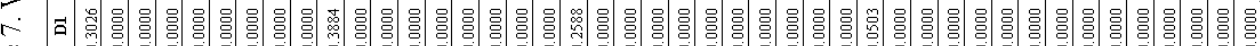

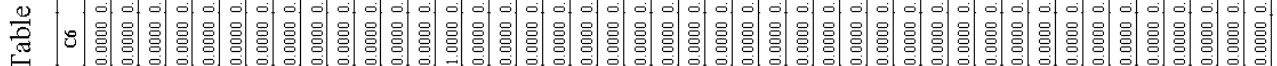

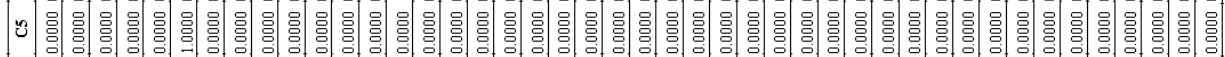

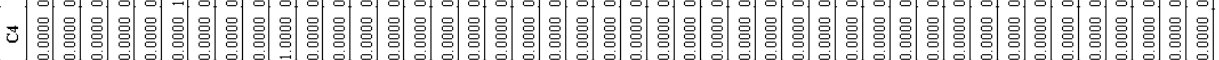

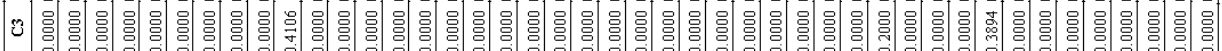

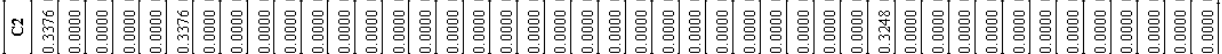

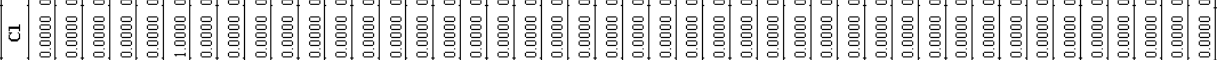

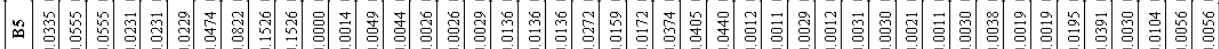

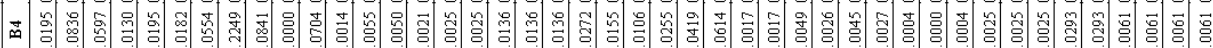

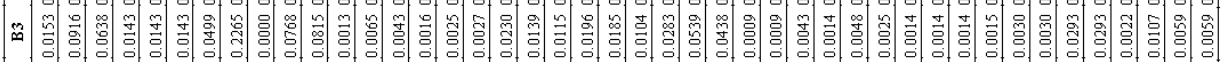

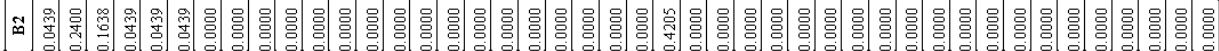

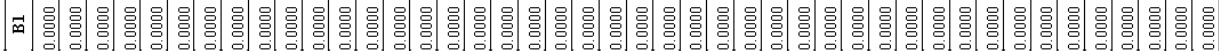

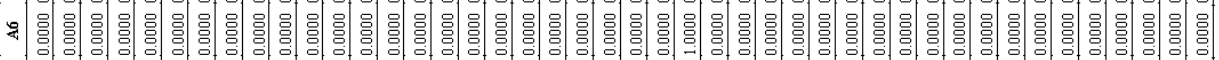

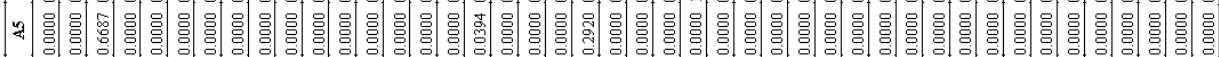

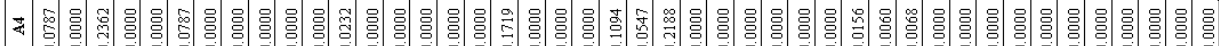

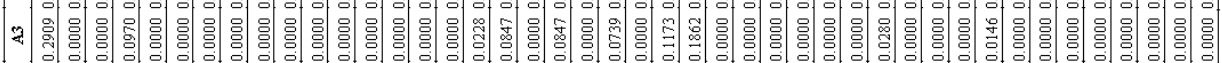

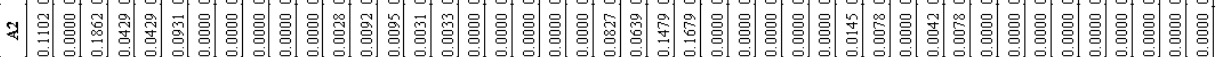

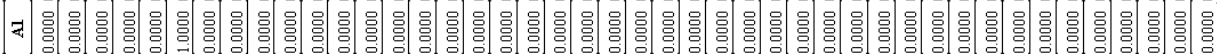

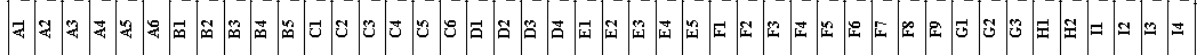

Co-published by Atlantis Press and Taylor \& Francis

Copyright: the authors

629 


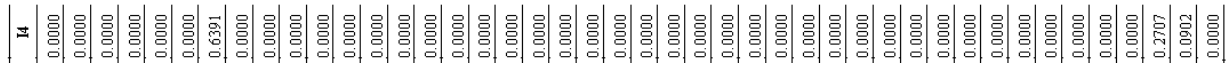

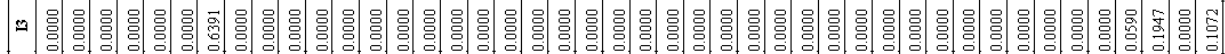

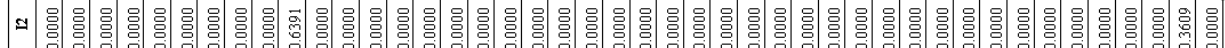

=

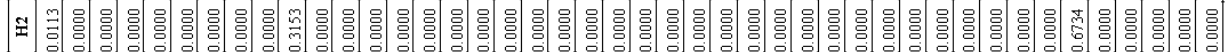

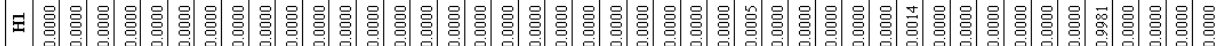

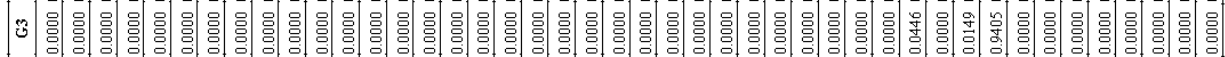

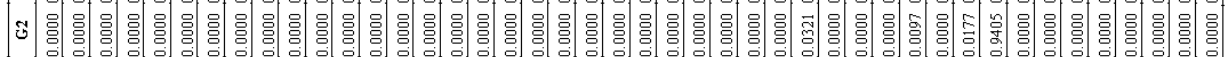

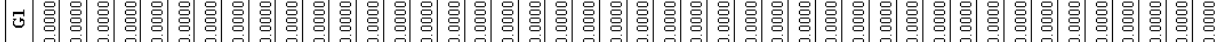

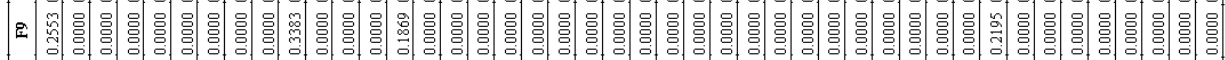

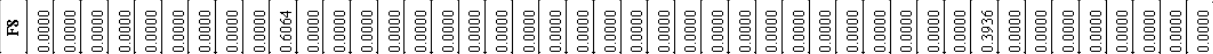

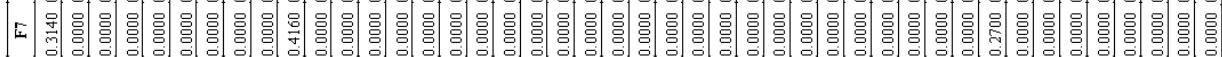

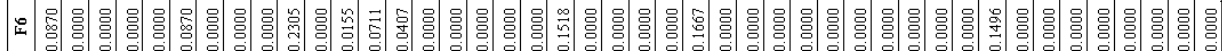

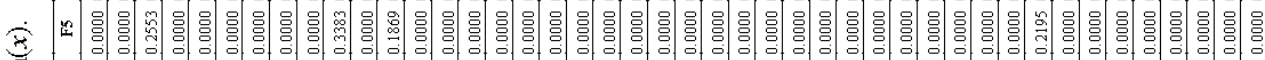

至

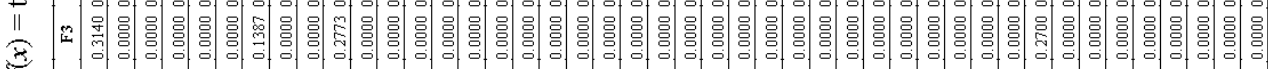

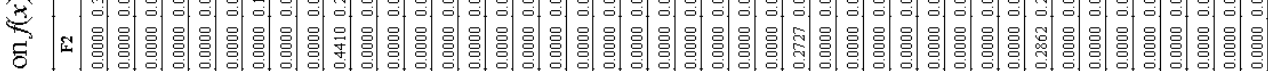

密

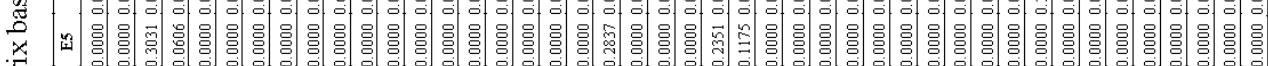

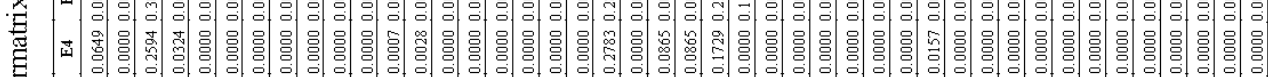

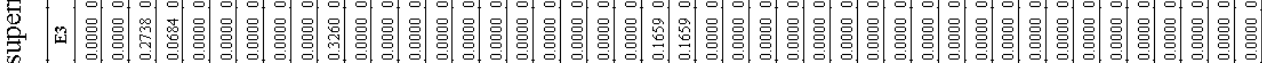

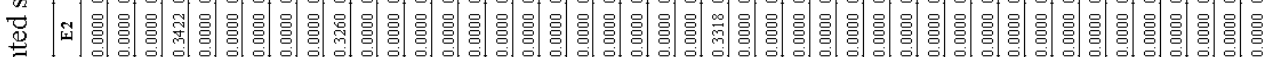

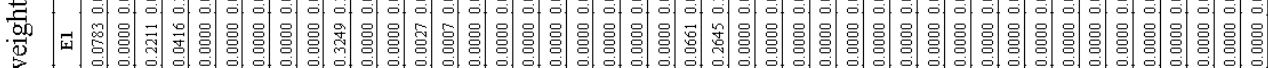

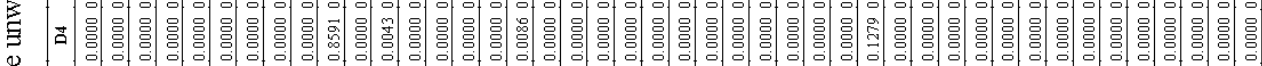

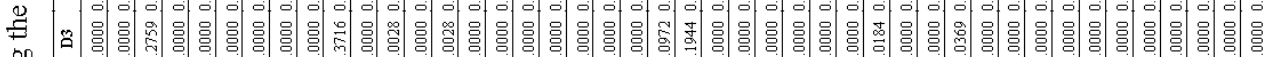

而

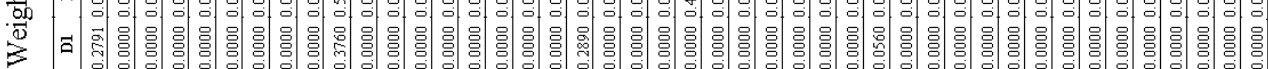

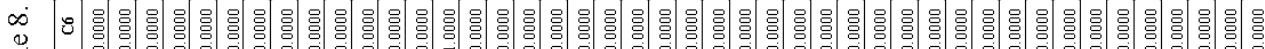

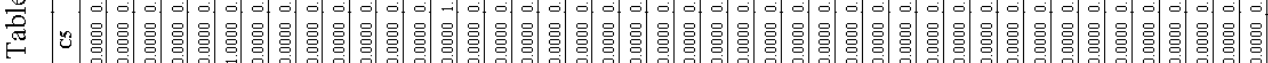

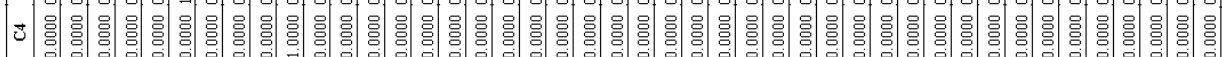

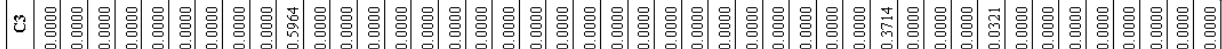

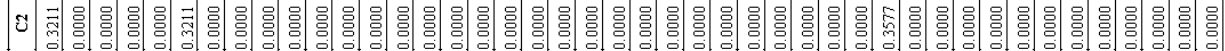

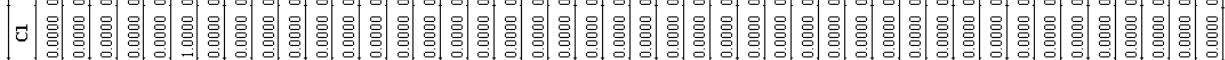

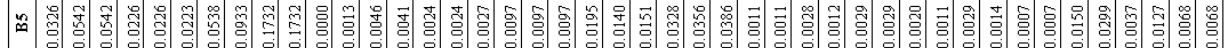

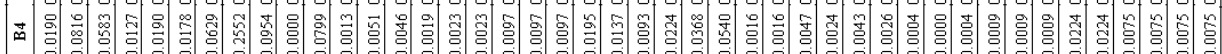

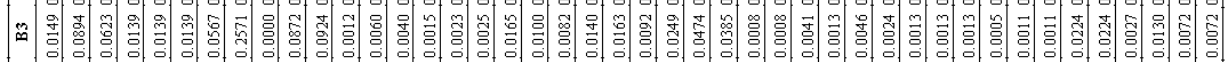

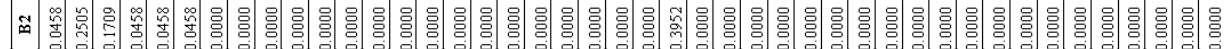

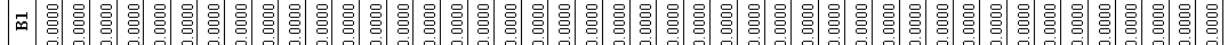

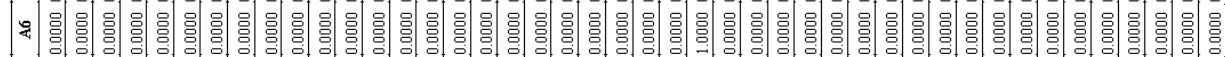

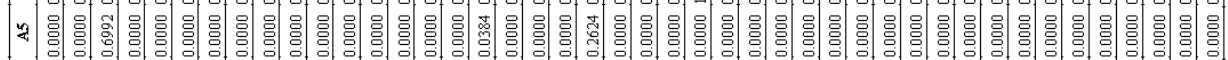

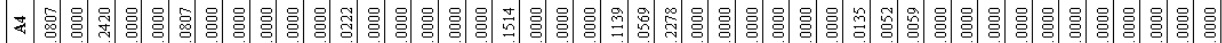

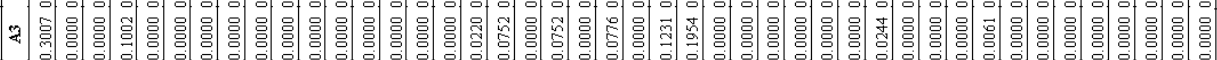

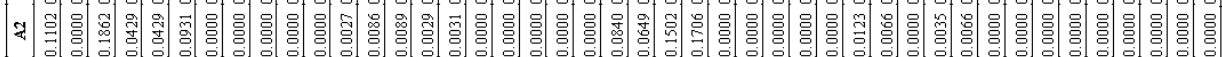

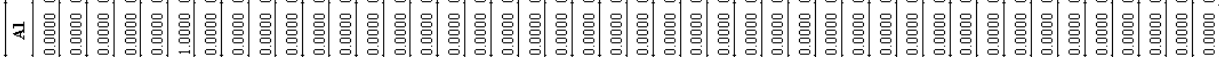

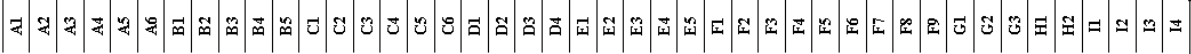

Co-published by Atlantis Press and Taylor \& Francis

Copyright: the authors

630 


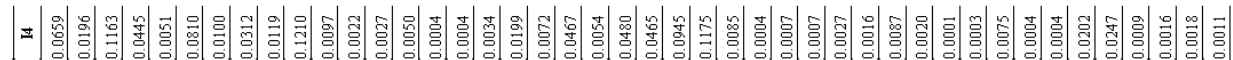

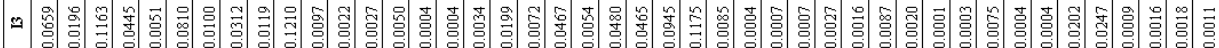

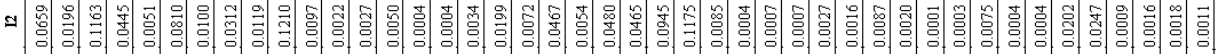

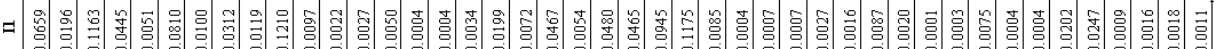

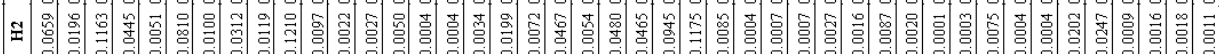

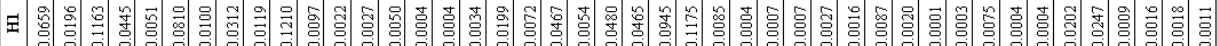

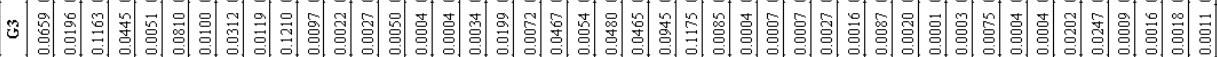

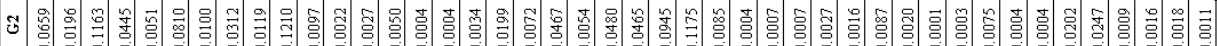

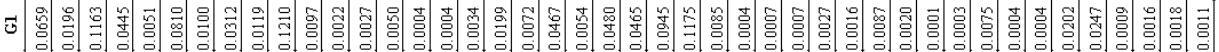

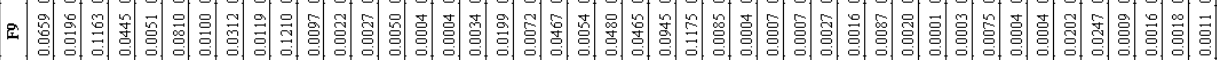

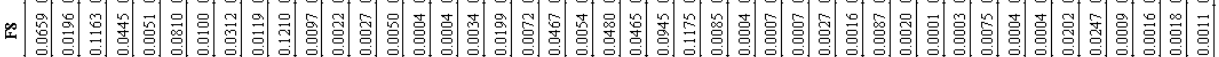

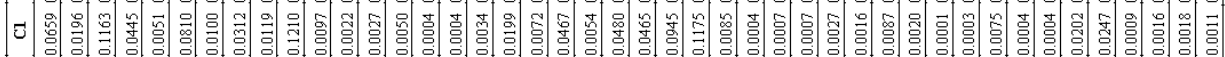

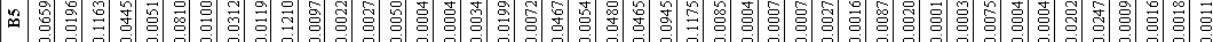

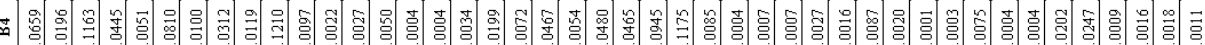

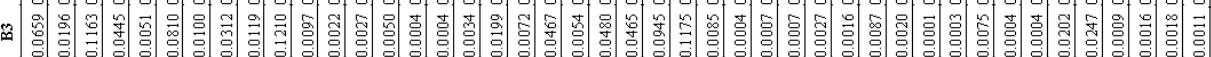

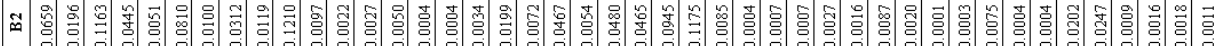

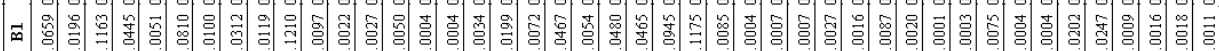

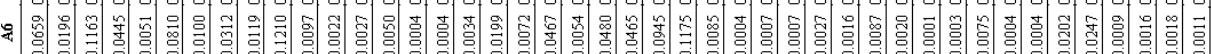

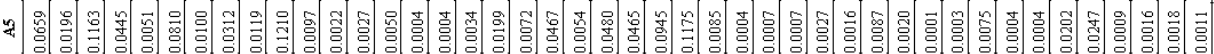

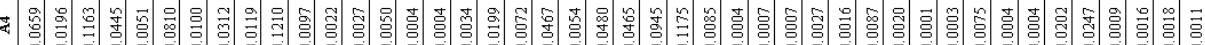
7

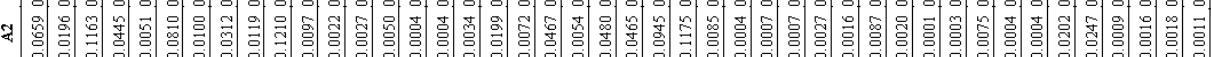

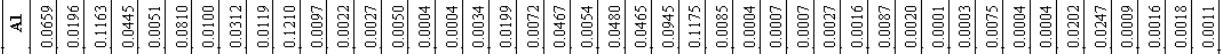

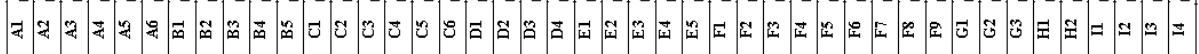




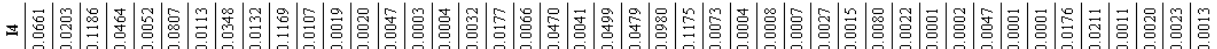

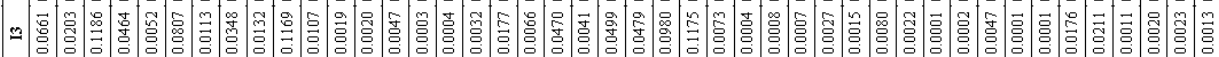

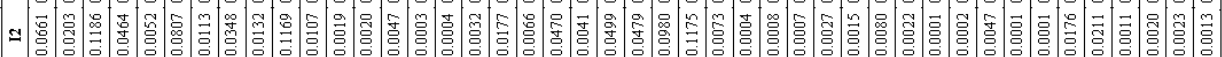

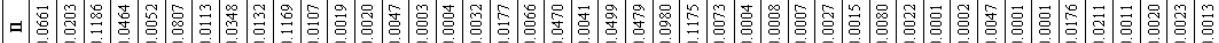

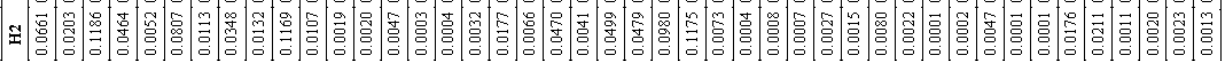

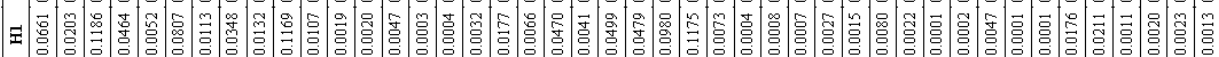

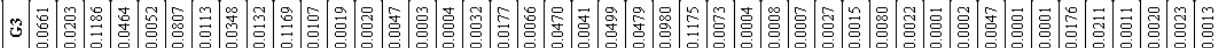

₹

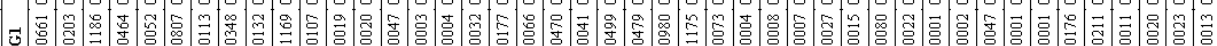

递番

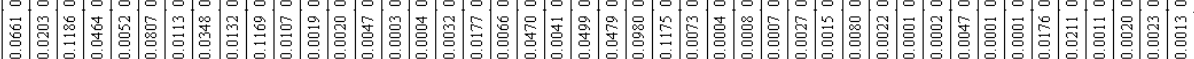

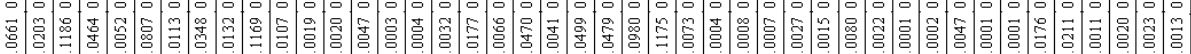

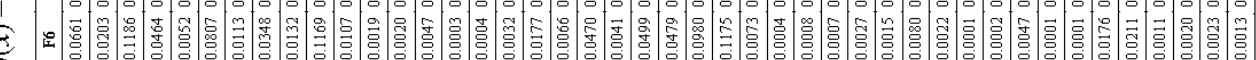

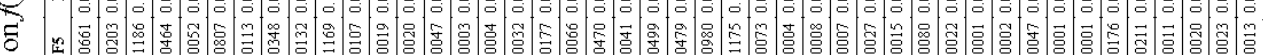

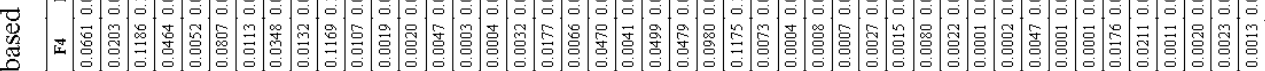

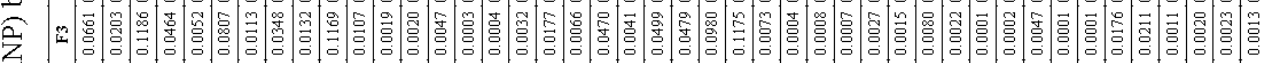

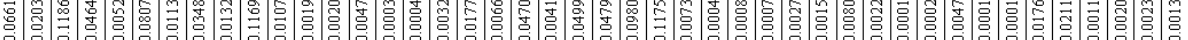

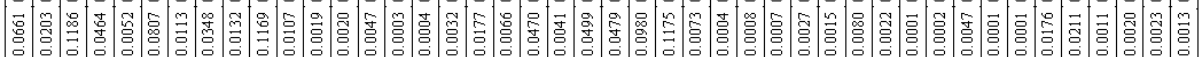

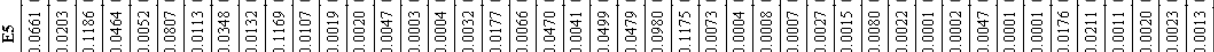

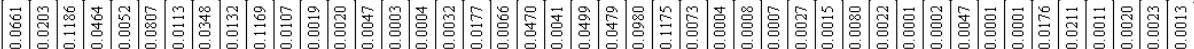

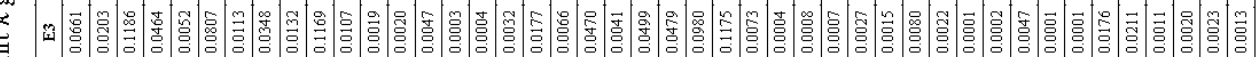

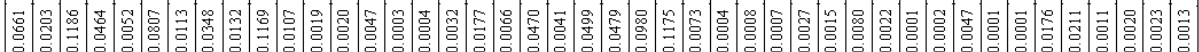

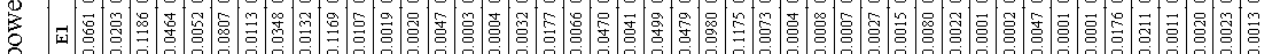

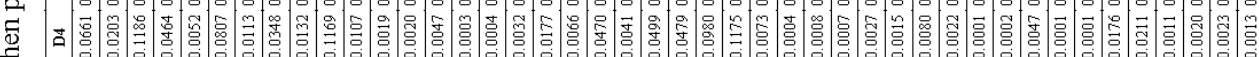

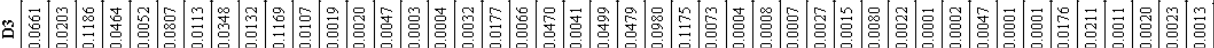

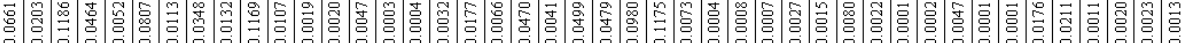

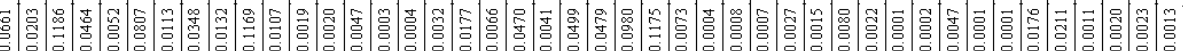

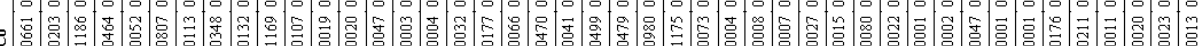

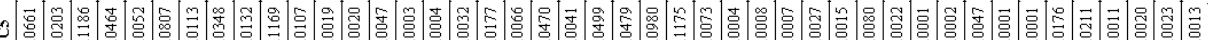

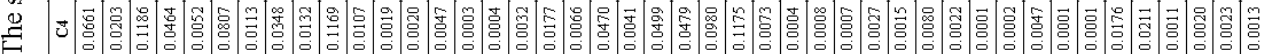

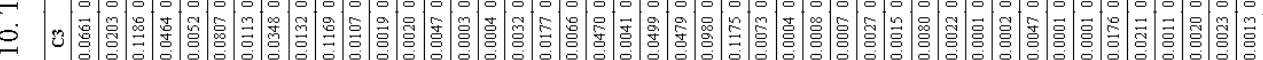

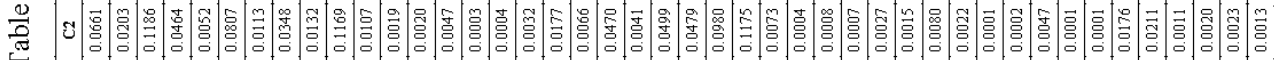

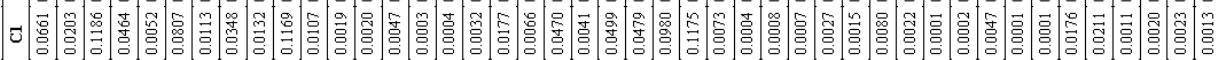

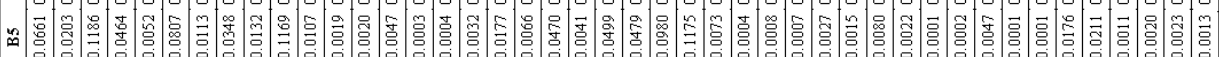

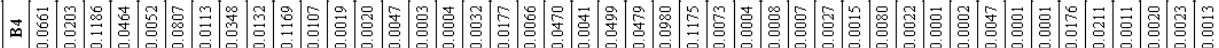

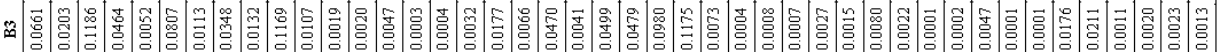

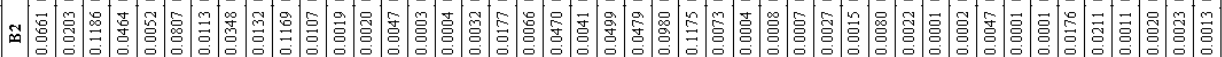

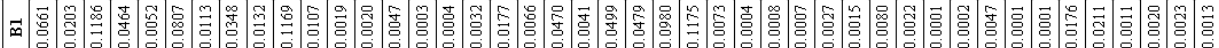

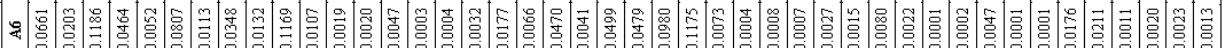

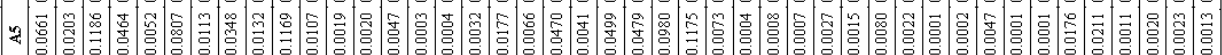

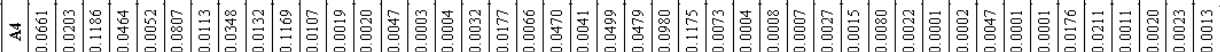

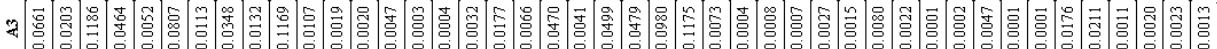

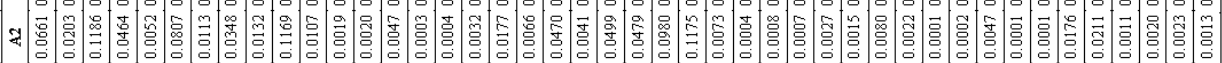

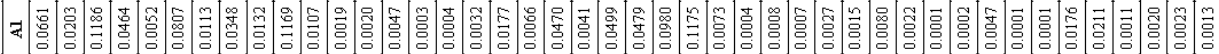

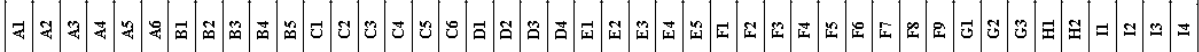


Table 11. Total grades of alternatives based on $f(x)=x$.

\begin{tabular}{|c|c|c|c|c|c|c|c|c|c|c|c|c|c|}
\hline \multirow{2}{*}{$\begin{array}{c}\begin{array}{c}\text { Sub } \\
\text { Factor }\end{array} \\
\text { A1 }\end{array}$} & \multirow{2}{*}{$\begin{array}{c}\begin{array}{c}\text { Corresponding } \\
\text { Weight }\end{array} \\
0.0659\end{array}$} & \multicolumn{2}{|c|}{ School A } & \multicolumn{2}{|c|}{ School B } & \multicolumn{2}{|c|}{ School C } & \multicolumn{2}{|c|}{ School D } & \multicolumn{2}{|c|}{ School E } & \multicolumn{2}{|c|}{ School F } \\
\hline & & 1 & 0.066 & 1 & 0.066 & 1 & 0.066 & 1 & 0.066 & 1 & 0.066 & 1 & 0.066 \\
\hline A2 & 0.0196 & 0.8 & 0.016 & 0.8 & 0.016 & 1 & 0.020 & 1 & 0.020 & 1 & 0.020 & 1 & 0.020 \\
\hline $\mathbf{A 3}$ & 0.1163 & 1 & 0.116 & 1 & 0.116 & 1 & 0.116 & 0.8 & 0.093 & 1 & 0.116 & 1 & 0.116 \\
\hline A4 & 0.0445 & 1 & 0.044 & 1 & 0.044 & 1 & 0.044 & 1 & 0.044 & 1 & 0.044 & 1 & 0.044 \\
\hline A5 & 0.0051 & 1 & 0.005 & 1 & 0.005 & 1 & 0.005 & 1 & 0.005 & 1 & 0.005 & 1 & 0.005 \\
\hline A6 & 0.0810 & 0 & 0.000 & 0 & 0.000 & 0 & 0.000 & 1 & 0.081 & 0 & 0.000 & 0 & 0.000 \\
\hline B1 & 0.0100 & 1 & 0.010 & 1 & 0.010 & 0.8 & 0.008 & 0.8 & 0.008 & 1 & 0.010 & 1 & 0.010 \\
\hline B2 & 0.0312 & 1 & 0.031 & 1 & 0.031 & 0.8 & 0.025 & 1 & 0.031 & 1 & 0.031 & 0.8 & 0.025 \\
\hline B3 & 0.0119 & 1 & 0.012 & 1 & 0.012 & 1 & 0.012 & 0.8 & 0.009 & 0.8 & 0.009 & 1 & 0.012 \\
\hline B4 & 0.1210 & 0.8 & 0.097 & 1 & 0.121 & 1 & 0.121 & 0.8 & 0.097 & 1 & 0.121 & 1 & 0.121 \\
\hline B5 & 0.0097 & 0.8 & 0.008 & 0.8 & 0.008 & 1 & 0.010 & 0.8 & 0.008 & 1 & 0.010 & 1 & 0.010 \\
\hline $\mathrm{C} 1$ & 0.0022 & 1 & 0.002 & 1 & 0.002 & 1 & 0.002 & 1 & 0.002 & 1 & 0.002 & 1 & 0.002 \\
\hline $\mathrm{C} 2$ & 0.0027 & 1 & 0.003 & 1 & 0.003 & 1 & 0.003 & 1 & 0.003 & 1 & 0.003 & 1 & 0.003 \\
\hline $\mathrm{C} 3$ & 0.0050 & 1 & 0.005 & 1 & 0.005 & 1 & 0.005 & 1 & 0.005 & 0 & 0.000 & 0 & 0.000 \\
\hline $\mathrm{C} 4$ & 0.0004 & 0 & 0.000 & 0 & 0.000 & 0 & 0.000 & 0 & 0.000 & 1 & 0.000 & 0 & 0.000 \\
\hline C5 & 0.0004 & 1 & 0.000 & 1 & 0.000 & 1 & 0.000 & 0 & 0.000 & 1 & 0.000 & 1 & 0.000 \\
\hline C6 & 0.0034 & 1 & 0.003 & 1 & 0.003 & 0 & 0.000 & 0 & 0.000 & 1 & 0.003 & 1 & 0.003 \\
\hline D1 & 0.0199 & 1 & 0.020 & 1 & 0.020 & 1 & 0.020 & 1 & 0.020 & 1 & 0.020 & 1 & 0.020 \\
\hline D2 & 0.0072 & 1 & 0.007 & 1 & 0.007 & 1 & 0.007 & 1 & 0.007 & 1 & 0.007 & 1 & 0.007 \\
\hline D3 & 0.0467 & 0.6 & 0.028 & 0 & 0.000 & 1 & 0.047 & 0.4 & 0.019 & 1 & 0.047 & 0.8 & 0.037 \\
\hline D4 & 0.0054 & 0 & 0.000 & 1 & 0.005 & 1 & 0.005 & 1 & 0.005 & 1 & 0.005 & 1 & 0.005 \\
\hline E1 & 0.0480 & 1 & 0.048 & 1 & 0.048 & 1 & 0.048 & 1 & 0.048 & 1 & 0.048 & 1 & 0.048 \\
\hline E2 & 0.0465 & 0 & 0.000 & 1 & 0.047 & 0 & 0.000 & 1 & 0.047 & 1 & 0.047 & 0 & 0.000 \\
\hline E3 & 0.0945 & 0 & 0.000 & 0 & 0.000 & 1 & 0.094 & 1 & 0.094 & 0 & 0.000 & 1 & 0.094 \\
\hline E4 & 0.1175 & 1 & 0.118 & 0 & 0.000 & 1 & 0.118 & 1 & 0.118 & 1 & 0.118 & 0 & 0.000 \\
\hline E5 & 0.0085 & 1 & 0.009 & 1 & 0.009 & 1 & 0.009 & 1 & 0.009 & 1 & 0.009 & 1 & 0.009 \\
\hline F1 & 0.0004 & 1 & 0.000 & 0 & 0.000 & 0 & 0.000 & 0 & 0.000 & 1 & 0.000 & 0 & 0.000 \\
\hline F2 & 0.0007 & 1 & 0.001 & 0 & 0.000 & 1 & 0.001 & 1 & 0.001 & 1 & 0.001 & 1 & 0.001 \\
\hline F3 & 0.0007 & 1 & 0.001 & 1 & 0.001 & 1 & 0.001 & 1 & 0.001 & 1 & 0.001 & 1 & 0.001 \\
\hline F4 & 0.0027 & 1 & 0.003 & 1 & 0.003 & 1 & 0.003 & 1 & 0.003 & 1 & 0.003 & 1 & 0.003 \\
\hline F5 & 0.0016 & 1 & 0.002 & 1 & 0.002 & 1 & 0.002 & 1 & 0.002 & 1 & 0.002 & 1 & 0.002 \\
\hline F6 & 0.0087 & 1 & 0.009 & 1 & 0.009 & 1 & 0.009 & 1 & 0.009 & 1 & 0.009 & 1 & 0.009 \\
\hline F7 & 0.0020 & 0 & 0.000 & 0 & 0.000 & 0 & 0.000 & 0 & 0.000 & 1 & 0.002 & 1 & 0.002 \\
\hline F8 & 0.0001 & 1 & 0.000 & 1 & 0.000 & 0 & 0.000 & 0 & 0.000 & 1 & 0.000 & 0 & 0.000 \\
\hline F9 & 0.0003 & 1 & 0.000 & 1 & 0.000 & 1 & 0.000 & 1 & 0.000 & 1 & 0.000 & 1 & 0.000 \\
\hline G1 & 0.0075 & 1 & 0.008 & 1 & 0.008 & 1 & 0.008 & 1 & 0.008 & 0.8 & 0.006 & 1 & 0.008 \\
\hline G2 & 0.0004 & 0.8 & 0.000 & 1 & 0.000 & 0.8 & 0.000 & 0.8 & 0.000 & 0.8 & 0.000 & 1 & 0.000 \\
\hline G3 & 0.0004 & 1 & 0.000 & 1 & 0.000 & 0.8 & 0.000 & 1 & 0.000 & 0.8 & 0.000 & 1 & 0.000 \\
\hline G4 & 0.0202 & 1 & 0.020 & 1 & 0.020 & 1 & 0.020 & 0.8 & 0.016 & 0.8 & 0.016 & 0.8 & 0.016 \\
\hline H1 & 0.0247 & 1 & 0.025 & 1 & 0.025 & 1 & 0.025 & 0.8 & 0.020 & 0.8 & 0.020 & 0.8 & 0.020 \\
\hline H2 & 0.0009 & 1 & 0.001 & 1 & 0.001 & 1 & 0.001 & 1 & 0.001 & 1 & 0.001 & 1 & 0.001 \\
\hline H3 & 0.0016 & 1 & 0.002 & 1 & 0.002 & 1 & 0.002 & 1 & 0.002 & 1 & 0.002 & 1 & 0.002 \\
\hline I1 & 0.0018 & 1 & 0.002 & 1 & 0.002 & 1 & 0.002 & 1 & 0.002 & 1 & 0.002 & 1 & 0.002 \\
\hline \multirow[t]{3}{*}{ I 2} & 0.0011 & 1 & 0.001 & 1 & 0.001 & 1 & 0.001 & 1 & 0.001 & 1 & 0.001 & 1 & 0.001 \\
\hline & Total Grade: & & 0.721499 & & 0.6510136 & & 0.857832 & & 0.902474 & & 0.806544 & & 0.7245182 \\
\hline & $\begin{array}{c}\text { Total Grade } \\
(\% 100):\end{array}$ & & 72.1499 & & 65.10136 & & 85.7832 & & 90.2474 & & 80.6544 & & 72.45182 \\
\hline
\end{tabular}


Table 12. Total grades of alternatives based on $f(x)=\tanh (x)$.

\begin{tabular}{|c|c|c|c|c|c|c|c|c|c|c|c|c|c|}
\hline \multirow{2}{*}{$\begin{array}{c}\begin{array}{c}\text { Sub } \\
\text { Factor }\end{array} \\
\mathbf{A 1}\end{array}$} & \multirow{2}{*}{$\begin{array}{c}\begin{array}{c}\text { Corresponding } \\
\text { Weight }\end{array} \\
0.0661\end{array}$} & \multicolumn{2}{|c|}{ School A } & \multicolumn{2}{|c|}{ School B } & \multicolumn{2}{|c|}{ School C } & \multicolumn{2}{|c|}{ School D } & \multicolumn{2}{|c|}{ School E } & \multicolumn{2}{|c|}{ School F } \\
\hline & & 1 & 0.066 & 1 & 0.066 & 1 & 0.066 & 1 & 0.066 & 1 & 0.066 & 1 & 0.066 \\
\hline $\mathbf{A 2}$ & 0.0203 & 0.8 & 0.016 & 0.8 & 0.016 & 1 & 0.020 & 1 & 0.020 & 1 & 0.020 & 1 & 0.020 \\
\hline A3 & 0.1186 & 1 & 0.119 & 1 & 0.119 & 1 & 0.119 & 0.8 & 0.095 & 1 & 0.119 & 1 & 0.119 \\
\hline A4 & 0.0464 & 1 & 0.046 & 1 & 0.046 & 1 & 0.046 & 1 & 0.046 & 1 & 0.046 & 1 & 0.046 \\
\hline A5 & 0.0052 & 1 & 0.005 & 1 & 0.005 & 1 & 0.005 & 1 & 0.005 & 1 & 0.005 & 1 & 0.005 \\
\hline A6 & 0.0807 & 0 & 0.000 & 0 & 0.000 & 0 & 0.000 & 1 & 0.081 & 0 & 0.000 & 0 & 0.000 \\
\hline B1 & 0.0113 & 1 & 0.011 & 1 & 0.011 & 0.8 & 0.009 & 0.8 & 0.009 & 1 & 0.011 & 1 & 0.011 \\
\hline B2 & 0.0348 & 1 & 0.035 & 1 & 0.035 & 0.8 & 0.028 & 1 & 0.035 & 1 & 0.035 & 0.8 & 0.028 \\
\hline B3 & 0.0132 & 1 & 0.013 & 1 & 0.013 & 1 & 0.013 & 0.8 & 0.011 & 0.8 & 0.011 & 1 & 0.013 \\
\hline B4 & 0.1169 & 0.8 & 0.094 & 1 & 0.117 & 1 & 0.117 & 0.8 & 0.094 & 1 & 0.117 & 1 & 0.117 \\
\hline B5 & 0.0107 & 0.8 & 0.009 & 0.8 & 0.009 & 1 & 0.011 & 0.8 & 0.009 & 1 & 0.011 & 1 & 0.011 \\
\hline $\mathrm{C} 1$ & 0.0019 & 1 & 0.002 & 1 & 0.002 & 1 & 0.002 & 1 & 0.002 & 1 & 0.002 & 1 & 0.002 \\
\hline $\mathrm{C} 2$ & 0.0020 & 1 & 0.002 & 1 & 0.002 & 1 & 0.002 & 1 & 0.002 & 1 & 0.002 & 1 & 0.002 \\
\hline $\mathrm{C} 3$ & 0.0047 & 1 & 0.005 & 1 & 0.005 & 1 & 0.005 & 1 & 0.005 & 0 & 0.000 & 0 & 0.000 \\
\hline $\mathrm{C} 4$ & 0.0003 & 0 & 0.000 & 0 & 0.000 & 0 & 0.000 & 0 & 0.000 & 1 & 0.000 & 0 & 0.000 \\
\hline C5 & 0.0004 & 1 & 0.000 & 1 & 0.000 & 1 & 0.000 & 0 & 0.000 & 1 & 0.000 & 1 & 0.000 \\
\hline C6 & 0.0032 & 1 & 0.003 & 1 & 0.003 & 0 & 0.000 & 0 & 0.000 & 1 & 0.003 & 1 & 0.003 \\
\hline D1 & 0.0177 & 1 & 0.018 & 1 & 0.018 & 1 & 0.018 & 1 & 0.018 & 1 & 0.018 & 1 & 0.018 \\
\hline D2 & 0.0066 & 1 & 0.007 & 1 & 0.007 & 1 & 0.007 & 1 & 0.007 & 1 & 0.007 & 1 & 0.007 \\
\hline D3 & 0.0470 & 0.6 & 0.028 & 0 & 0.000 & 1 & 0.047 & 0.4 & 0.019 & 1 & 0.047 & 0.8 & 0.038 \\
\hline D4 & 0.0041 & 0 & 0.000 & 1 & 0.004 & 1 & 0.004 & 1 & 0.004 & 1 & 0.004 & 1 & 0.004 \\
\hline E1 & 0.0499 & 1 & 0.050 & 1 & 0.050 & 1 & 0.050 & 1 & 0.050 & 1 & 0.050 & 1 & 0.050 \\
\hline E2 & 0.0479 & 0 & 0.000 & 1 & 0.048 & 0 & 0.000 & 1 & 0.048 & 1 & 0.048 & 0 & 0.000 \\
\hline E3 & 0.0980 & 0 & 0.000 & 0 & 0.000 & 1 & 0.098 & 1 & 0.098 & 0 & 0.000 & 1 & 0.098 \\
\hline E4 & 0.1175 & 1 & 0.117 & 0 & 0.000 & 1 & 0.117 & 1 & 0.117 & 1 & 0.117 & 0 & 0.000 \\
\hline E5 & 0.0073 & 1 & 0.007 & 1 & 0.007 & 1 & 0.007 & 1 & 0.007 & 1 & 0.007 & 1 & 0.007 \\
\hline F1 & 0.0004 & 1 & 0.000 & 0 & 0.000 & 0 & 0.000 & 0 & 0.000 & 1 & 0.000 & 0 & 0.000 \\
\hline F2 & 0.0008 & 1 & 0.001 & 0 & 0.000 & 1 & 0.001 & 1 & 0.001 & 1 & 0.001 & 1 & 0.001 \\
\hline F3 & 0.0007 & 1 & 0.001 & 1 & 0.001 & 1 & 0.001 & 1 & 0.001 & 1 & 0.001 & 1 & 0.001 \\
\hline F4 & 0.0027 & 1 & 0.003 & 1 & 0.003 & 1 & 0.003 & 1 & 0.003 & 1 & 0.003 & 1 & 0.003 \\
\hline F5 & 0.0015 & 1 & 0.001 & 1 & 0.001 & 1 & 0.001 & 1 & 0.001 & 1 & 0.001 & 1 & 0.001 \\
\hline F6 & 0.0080 & 1 & 0.008 & 1 & 0.008 & 1 & 0.008 & 1 & 0.008 & 1 & 0.008 & 1 & 0.008 \\
\hline F7 & 0.0022 & 0 & 0.000 & 0 & 0.000 & 0 & 0.000 & 0 & 0.000 & 1 & 0.002 & 1 & 0.002 \\
\hline F8 & 0.0001 & 1 & 0.000 & 1 & 0.000 & 0 & 0.000 & 0 & 0.000 & 1 & 0.000 & 0 & 0.000 \\
\hline F9 & 0.0002 & 1 & 0.000 & 1 & 0.000 & 1 & 0.000 & 1 & 0.000 & 1 & 0.000 & 1 & 0.000 \\
\hline G1 & 0.0047 & 1 & 0.005 & 1 & 0.005 & 1 & 0.005 & 1 & 0.005 & 0.8 & 0.004 & 1 & 0.005 \\
\hline G2 & 0.0001 & 0.8 & 0.000 & 1 & 0.000 & 0.8 & 0.000 & 0.8 & 0.000 & 0.8 & 0.000 & 1 & 0.000 \\
\hline G3 & 0.0001 & 1 & 0.000 & 1 & 0.000 & 0.8 & 0.000 & 1 & 0.000 & 0.8 & 0.000 & 1 & 0.000 \\
\hline G4 & 0.0176 & 1 & 0.018 & 1 & 0.018 & 1 & 0.018 & 0.8 & 0.014 & 0.8 & 0.014 & 0.8 & 0.014 \\
\hline H1 & 0.0211 & 1 & 0.021 & 1 & 0.021 & 1 & 0.021 & 0.8 & 0.017 & 0.8 & 0.017 & 0.8 & 0.017 \\
\hline H2 & 0.0011 & 1 & 0.001 & 1 & 0.001 & 1 & 0.001 & 1 & 0.001 & 1 & 0.001 & 1 & 0.001 \\
\hline H3 & 0.0020 & 1 & 0.002 & 1 & 0.002 & 1 & 0.002 & 1 & 0.002 & 1 & 0.002 & 1 & 0.002 \\
\hline I1 & 0.0023 & 1 & 0.002 & 1 & 0.002 & 1 & 0.002 & 1 & 0.002 & 1 & 0.002 & 1 & 0.002 \\
\hline \multirow[t]{3}{*}{ I2 } & 0.0013 & 1 & 0.001 & 1 & 0.001 & 1 & 0.001 & 1 & 0.001 & 1 & 0.001 & 1 & 0.001 \\
\hline & Total Grade: & & 0.7183982 & & 0.6468518 & & 0.8558624 & & 0.9031972 & & 0.8052338 & & 0.724291 \\
\hline & $\begin{array}{c}\text { Total Grade } \\
\text { (\%100): }\end{array}$ & & 71.83982 & & 64.68518 & & 85.58624 & & 90.31972 & & 80.52338 & & 72.4291 \\
\hline
\end{tabular}

Co-published by Atlantis Press and Taylor \& Francis

Copyright: the authors 
Table 13. Cost/Benefit analysis of the alternatives.

\begin{tabular}{|c|c|c|c|c|c|c|c|}
\hline & & & & $\mathbf{f}(\mathbf{x})=\mathbf{x}$ & $f(x)=\tanh x$ & $f(x)=x$ & $f(x)=\tanh x$ \\
\hline Alternative & $\begin{array}{c}\text { Annual Fee } \\
\text { (Turkish Lira) }\end{array}$ & Normalized & Cost & Total Grades & Total Grades & $\begin{array}{c}\text { Cost/Benefit } \\
\text { Ratio }\end{array}$ & $\begin{array}{c}\text { Cost/Benefit } \\
\text { Ratio }\end{array}$ \\
\hline School A & 7000 & 0.152 & & 0.7215 & 0.7184 & 0.210 & 0.211 \\
\hline School B & 6500 & 0.141 & & 0.6510 & 0.6469 & 0.216 & 0.218 \\
\hline School C & 12500 & 0.271 & & 0.8578 & 0.8559 & 0.315 & 0.316 \\
\hline School D & 6600 & 0.143 & & 0.9025 & 0.9032 & 0.158 & 0.158 \\
\hline School E & 5200 & 0.113 & & 0.8065 & 0.8052 & 0.140 & 0.140 \\
\hline School F & 8400 & 0.182 & & 0.7245 & 0.7243 & 0.251 & 0.251 \\
\hline Total Cost & 46200 & & & & & & \\
\hline
\end{tabular}

